\title{
Pride and Prejudice
}

\section{Lesbian Families in Contemporary Sweden}

\author{
Anna Malmquist
}

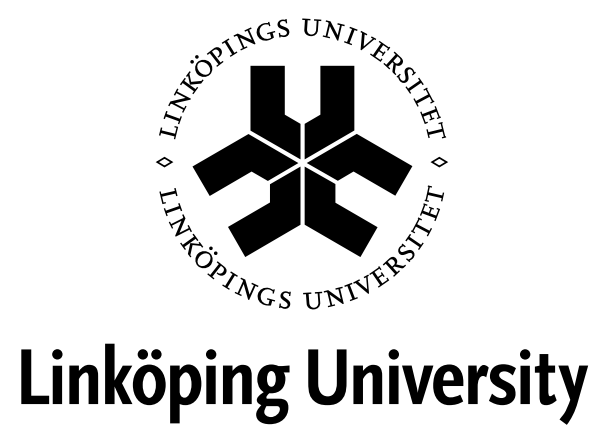

Linköping Studies in Arts and Science No. 642

Linköping Studies in Behavioural Science No. 191

Linköping University

Department of Behavioural Sciences and Learning

Linköping 2015 
Linköping Studies in Arts and Science $\cdot$ No. 642

Linköping Studies in Behavioural Science $・$ No. 191

At the Faculty of Arts and Science at Linköping University, research and doctoral studies are carried out within broad problem areas. Research is organized in interdisciplinary research environments and doctoral studies mainly in graduate schools. Jointly, they publish the series Linköping Studies in Arts and Science. This thesis comes from the Division of Psychology at the Department of Behavioural Sciences and Learning.

Distributed by:

Department of Behavioural Sciences and Learning

Linköping University

SE - 58183 Linköping

Anna Malmquist

Pride and Prejudice:

Lesbian Families in Contemporary Sweden

Cover painting: Kristin Winander

Upplaga 1:1

ISBN 978-91-7519-087-7

ISSN 0282-9800

ISSN 1654-2029

(C)Anna Malmquist

Department of Behavioural Sciences and Learning, 2015

Printed by: LiU-tryck, Linköping 2015 
To my children, Emil, Nils, Myran and Tove 

Färgen på barns ögon kommer från arvet, glittret i barns ögon kommer från miljön.

The colour of children's eyes comes from nature, the sparkle in children's eyes comes from nurture. 



\section{Abstract}

Options and possibilities for lesbian parents have changed fundamentally since the turn of the millennium. A legal change in 2003 enabled a same-sex couple to share legal parenthood of the same child. An additional legal change, in 2005, gave lesbian couples access to fertility treatment within public healthcare in Sweden. The present thesis focuses on families where two women share legal parenthood of their children. It aims to provide knowledge about lesbian parenting couples and their children, and to focus on the interplay between family members within lesbian families, and between family members and their surroundings. Furthermore, the thesis aims to visualize and analyse notions of heteronormativity and homonormativity in contemporary Sweden. The thesis draws on interviews with 118 parents in 61 families, and 12 children in 11 families. The participants' stories, descriptions, reflections and discourses have been analysed using discursive psychology and thematic analysis.

The thesis includes five empirical papers. Paper I focuses on encounters with healthcare professionals prior to and during pregnancy, at childbirth and during the early stages of parenthood. Paper II deals with the participants' experiences of second-parent adoption processes. Paper III focuses on equality in parenting relations. Paper IV focuses on encounters with fertility clinics within public healthcare. Paper V highlights the children's reflections and shows how the children talk about fathers and donors.

Keywords: lesbian family, same-sex parents, heteronormativity, homonormativity, fertility treatment, maternity care, healthcare, second-parent adoption, equality, donor, discursive psychology, thematic analysis 



\section{Empirical studies}

The thesis is based on the following original research papers:

I. Malmquist, A., \& Zetterqvist Nelson, K. (2014). Efforts to maintain a 'just great' story: Lesbian parents' talk about encounters with professionals in fertility clinics and maternal and child health care services. Feminism \& Psychology, 24(1), 56-73.

II. Malmquist, A. (2015). A crucial but strenuous process: Female same-sex couples' reflections on second-parent adoption. Journal of GLBT Family Studies. DOI: 10.1080/1550428X.2015.1019169

III. Malmquist, A. (2014). Women in lesbian relations: Construing equal or unequal parental roles? Psychology of Women Quarterly, pre-published on-line. DOI: $10.1177 / 0361684314537225$

IV. Rozental, A., \& Malmquist, A. (2015). Vulnerability and acceptance: Lesbian women's family making through assisted reproduction in Swedish public healthcare. Journal of GLBT Family Studies, 11(2), 127-150.

V. Malmquist, A., Möllerstrand, A., Wikström, M., \& Zetterqvist Nelson, K. (2014). 'A daddy is the same as a mummy': Swedish children in lesbian households talk about fathers and donors. Childhood, 21(1), 119-133. 



\section{Table of contents}

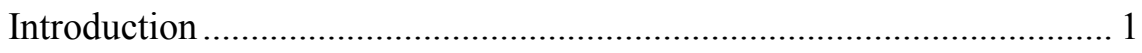

Contemporary lesbian families, in a time of legal recognition ............. 1

Lesbian families and modern family theory.......................................... 3

Queer theory and heteronormativity ................................................ 5

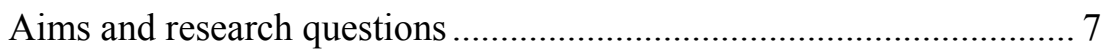

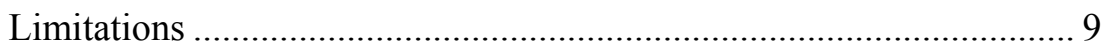

Previous research on lesbian parents and their children.......................... 11

International research on lesbian parenting ........................................ 11

Studies on lesbian family life and practices ................................... 13

Debating the research field ......................................................... 17

Research on lesbian families in Sweden ............................................. 18

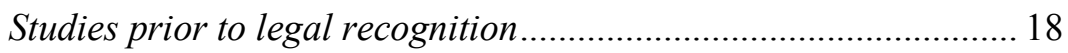

Studies in a time of legal recognition ............................................... 19

Other studies within the present research project........................... 21

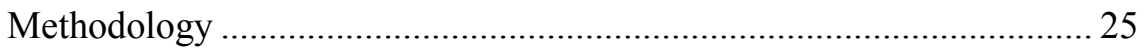

Social constructionism and post-structuralism................................... 25

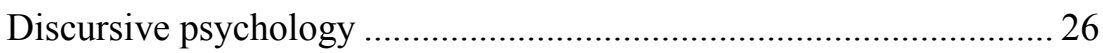

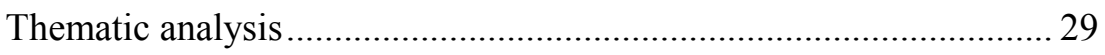

The studies: Participants and procedure .................................................. 31

Female couples with shared legal parenthood in Sweden .................... 31

Second-parent adoption families ..................................................... 32

Public fertility clinic families .......................................................... 34

Preferred paths to parenthood ........................................................ 35 
Interviewees and interviews in the present study ................................ 35

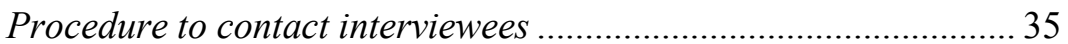

Participants and interviews in Paper I, II and III .......................... 38

Participants and interviews in Paper IV ......................................... 41

Participants and interviews in Paper $V$......................................... 42

Transcription and data analysis .......................................................... 43

Transcription and analysis in Paper I, II and III ........................... 43

Transcription and analysis in Paper $I V$ and $V$................................ 45

Ethical and methodological considerations ....................................... 45

Considerations on parent interviews................................................ 46

Considerations on child interviews ................................................. 49

Denominating the families: Same-sex families, lesbians, $L G B T Q$, mothers, father and donors ...................................................... 50

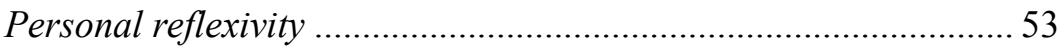

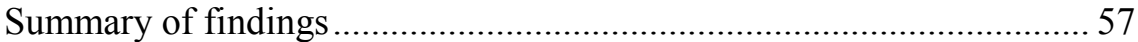

Findings in Paper I: On encounters with maternal and child healthcare

Findings in Paper II: On second-parent adoptions ............................. 58

Findings in Paper III: On equality in parental relationships................ 60

Findings in Paper IV: On encounters with public fertility clinics....... 61

Findings in Paper V: On children's talk about fathers and donors...... 62

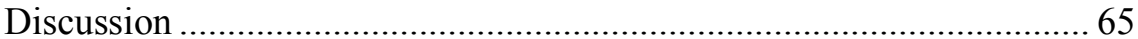

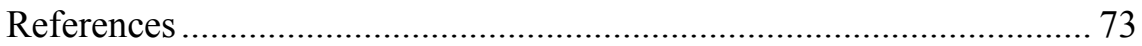

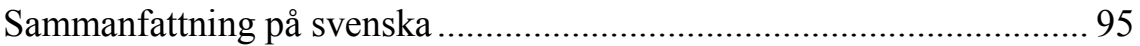

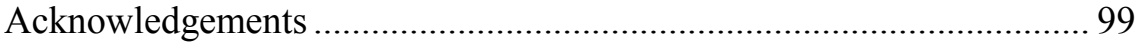




\title{
Chapter I
}

\author{
Introduction
}

\section{Contemporary lesbian families, in a time of legal recognition}

For a lesbian couple in Sweden with a longing to parent, options and possibilities have gone through dramatic changes since the turn of the millennium. In 1995, Swedish same-sex couples were given the possibility to register their partnership, a ground-breaking result for gay and lesbian political activism (SFS 1994:1117). As registered partners, a couple benefited from rights and obligations to one and another, almost identically to that of spouses in a different-sex couple - except for in one area: parenthood. When forming the registered partnership law, legislators excluded every part of the marriage law that regarded children. Unlike married spouses, registered partners were not allowed to adopt or to have any kind of assisted reproduction treatment. Consequently, a child could not have two legal parents of the same gender. The reason for excluding parenthood from the new legislation was clearly outlined in a report from the Swedish standing committee on civil-law legislation: it was not considered clear that a child's social and emotional development would be promoted in a family with same-sex parents (Betänkande från lagutskottet 1993/94:LU28).

However, only four years later, in 1999, the Swedish government appointed an inquiry to "investigate and analyse the conditions for children in homosexual families" (SOU 2001:10, p. 67), and give suggestions for how potential "unmotivated differences" (SOU 2001:10, p. 67) in legislation could be removed. The inquiry presented its results in 2001, suggesting that registered partners 
should be able to adopt, and that lesbian couples should have access to fertility treatment in public healthcare. Accordingly, same-sex couples were given rights to apply for adoption in 2003 (Proposition 2001/02:123), and lesbian couples were given access to assisted reproduction treatment in 2005 (Proposition 2004/05:137).

In just a decade, conditions for same-sex parenting couples had changed fundamentally. From a time when all regulations regarding children had effectively been excluded from legislation on same-sex couples, lesbian and gay families were now supported by Swedish law. A same-sex couple could share legal parenting with one another, and a lesbian couple could turn to a Swedish hospital for insemination or IVF treatment. Swedish legislation had come out of the closet and now recognized two mums or two dads as fully sufficient parents.

There are several paths to parenthood available for a female couple living in Sweden today. Treatment in public fertility clinics is available and often tax-funded. Assisted reproduction is also offered to lesbian couples in private clinics in many neighbouring countries. Self-insemination at home is an option both for those who desire a known sperm donor and for those who wish to share daily parenting responsibility with an involved father or two fathers in a male couple. Having more than two legal parents is however not permitted in Sweden (SFS 1949:381). For single women, fertility treatment in Swedish clinics is prohibited by law, despite the Swedish Parliament's vote in 2012 in favour of a legislative change. Women who do not live in couple relationships turn to fertility clinics abroad or do self-inseminations at home, if they desire pregnancy. For male couples or single men, no kind of assisted reproduction treatment is yet accessible in Swedish clinics (SFS 2006:351). Male couples and singles turn to fertility clinics abroad for surrogacy, and a male couple may share legal parenthood after second-parent adoption. Besides biologically grounded families, singles and same-sex couples may also parent foster children or adopt. Joint adoption has been legal for same-sex couples since 2003 (SFS 1949:381), but is rarely practiced (Bax, 2012, 29 March). Foreign adoptions are generally mediated through authorized adoption agencies, but the adoption agencies do not cooperate with any foreign organizations 
that allow same-sex adopters (Ottosson, 2015, 26 January). In 2009, a gender-neutral marriage law replaced the previous law on registered partnership, thus a couple can now marry regardless of gender (SFS 1987:230).

The legal changes have been significant. But what about the norms and social climate? Are they changing along with the legislation? Modern family theory and queer theory provide an important theoretical framework when questions on contemporary lesbian families are raised. This chapter continues with a short presentation of modern family theory and queer theory, and culminates with the aims and limitations of the present thesis.

\section{Lesbian families and modern family theory}

The lesbian family is often described as a new family form in the Western world (Anderssen, Amlie \& Ytterøy, 2002; Bos, van Balen $\&$ van den Boom, 2005). Such claims definitely give a limited picture. Lesbian families have gained legal recognition and public establishment during the past decades, but descriptions of female couples forming family life with children can be found long before this emancipation. An example from Sweden is the well-known journalist Barbro "Bang" Alving, who raised her daughter Ruffa, born in the 1930s, together with her female partner Loyce Sjöcrona (Alving \& Alving Olin, 2009). Likewise, many children have been conceived in different-sex intimacies, but later come to grow up with a same-sex couple (Golombok, Spencer \& Rutter, 1983; Patterson, 1992). During the 1990s, increasing numbers of lesbians had children through assisted reproduction, and American anthropologist Kath Weston (1991) described a lesbian baby boom, denominated a 'gayby-boom', in the United States. We are seeing a gayby-boom in Sweden as well, but it occurred later, during the 2000s (Gustavson \& Schmitt, 2011). Thus, the lesbian baby boom in Sweden coincides with the new laws.

Swedish families are often described to be on the forefront of gender equality (Ahrne, Roman \& Franzén, 2003; Holli, Magnusson \& Rönnblom, 2005; Magnusson, 2008; Ryan-Flood, 2009). A 
discourse on gender equality grew strong in Sweden during the 1960 s and 1970s, and huge political interventions were carried out to increase women's paid employment (Ahrne et al., 2003). Besides a political aim to include women in the workforce, Swedish official politics also aimed at involving fathers in the caretaking of children. In 1974, Sweden was first to allow fathers compensated parental leave (Johansson \& Klinth, 2008). The regulations on parental leave are today among the most generous, offering a long time off work for both mothers and fathers once a child is born or adopted. Thus, the Swedish welfare state continuously provides active politics to facilitate the combination of child caretaking and career - and the dual earner/dual carer model is the normative ideal. Expectations on caregiving fathers have had a specific impact on lesbian families. During the 1990s, a pioneer generation of lesbians had children (Zetterqvist Nelson, 2007). Among those women, a common path to parenthood was to turn to gay men for joint parenthood, and they argued for the importance of having a caring father taking part in the child's upbringing (Ryan-Flood, 2009; Zetterqvist Nelson, 2007).

Modern family theory engages with family life as it is being lived and practiced, rather than structured (Beck \& Beck-Gernsheim, 1995; Gubrium \& Holstein, 2006; Morgan, 1996, 2011; Silva \& Smart, 1999). Families in contemporary Western societies show huge variation in their forms and expressions. Therefore it is not reasonable to talk about 'the Family' as a stable concept. Rather, families could be expected to differ from one and another and change over time. British sociologist David Morgan (1996) talks about the doing of family life, as people form and negotiate relations in everyday practices. Such an approach accords well with the concept 'chosen families', launched in lesbian and gay studies (Weston, 1991; Weeks, Heaphy \& Donovan, 2001). Despite such a negotiable family concept, sociologist and standpoint feminist Dorothy Smith argues that the heterosexual nuclear family, with a married wife and husband and their children conceived through sexual intimacy, forms a normative ideal to which actual families relate (Smith, 1993). Accordingly, Elena Marie DiLapi claims that there is a motherhood hierarchy where "a heterosexual woman, of legal age, married in a traditional nuclear family, fertile, pregnant by intercourse with her husband, and wants to bear children" (DiLapi, 
1989, p.110) forms the ideal. A lesbian family, like many others, always comes out as deficient in relation to such normative ideals.

Related to modern family theory is also the field of childhood studies (Halldén, 2007; James, Jenks \& Prout, 1998; Wyness, 2012). Unlike how developmental psychology has described children's skills using stage theories, the childhood studies' tradition views childhood as a social construction. Children are seen as active agents who form childhood in culturally and historically situated contexts. Close attention is paid to the children's own perspectives, and studies often aim to make children's voices heard (Cummings \& Schermerhorn, 2003; Halldén, 2007; Hunleth, 2011; James \& James, 2008; Kellett, 2010; Woodhead \& Faulker, 2008; Wyness, 2012).

\section{Queer theory and heteronormativity}

Approaching lesbian families also calls attention to queer theory. The old invective word 'queer' was reclaimed in the late 1980s by non-heterosexual activists who found the labels 'gay' and 'lesbian' to be un-inclusive for the diversity of non-heterosexuals and conciliating towards dominant heterosexuality (see Clarke, Ellis, Peel \& Riggs, 2010; Kulick, 1996). The concept was soon adapted by scholars in the formation of queer theory. Drawing on French historian of ideas Michel Foucault's ground-breaking work The history of sexuality (1990a, 1990b, 1992, originally published in French in 1976-1984), 'heterosexuality' and 'homosexuality' were revealed to be social constructions invented in the late 19th century. Rather than considering heterosexuality to be natural and selfevident, queer theorists showed how heterosexuality was constructed as natural and self-evident through the cultural production of normativity, heteronormativity (Cameron \& Kulick, 2003; Kitzinger, 2005; Land \& Kitzinger, 2005). Approaching lesbian parenting through the lens of heteronormativity means adhering to how lesbian parenthood is being negotiated and formed in a societal context where heterosexuality is privileged and construed as natural, and not least: where heterosexual intimacy is thought of as the 'natural' child conception method with a mother 
and a father as 'natural' parents. Sociologist Róisín Ryan-Flood (2009) highlights how the production of heteronormativity varies between contexts, thus she launches the concept in the plural, heteronormativities.

Theories on heteronormativity could be useful in studies that deal with identity, family life, relationships and intimacies in selfidentified heterosexuals (see Archakis \& Lampropoulou, 2009; Kitzinger, 2005; Magnusson, 2006; Ward, 2008). When heteronormativity is drawn on in studies on self-identified nonheterosexuals, it is shown that non-heterosexuals are construed as 'other' or 'deviant' (see Land \& Kitzinger, 2005). Their family life and intimacies are viewed as unnatural or extraordinary, in a way that puts non-heterosexuals in a position where they must defend their identities and relations, or feel required to inform others about their way of living. The process of coming out is closely tied to heteronormativity, because when a heterosexual identity is taken for granted, one's non-heterosexual identity has to be explicitly claimed in order to become visible. Besides being othered through the production of heteronormativity, lesbians and other nonheterosexuals have also been shown to adjust to heteronormative standards and ideals, as they form their family life and intimate relationships (Warner, 1999). For example, same-sex marriage is often regarded as a liberal legitimization of same-sex unions, but could also be interpreted as a way of adjusting same-sex couples to heteronormative expectations on family life. Adjustments to heteronormativity among lesbians and gays are sometimes referred to as homonormativity (Ahmed, 2006; Duggan, 2004; Robinson, 2012). In my empirical papers, I use the concept somewhat differently, to describe the specific norms and ideas on family life and relationships that emerge among non-heterosexuals, in this case lesbians, themselves.

When same-sex parenting is the topic, queer theory is not easily separable from postmodern gender theory (see Butler, 2006; Kessler \& McKenna, 1985). Only a few decades ago, parenthood and homosexuality were generally seen as incompatible, as an oxymoron (Weston, 1991), while close cultural bonds connected parenthood to heterosexuality. Simultaneously, heterosexual spouses, with their 
different genders, are often expected to form different parental roles and fulfil different parental functions, with the father being the main breadwinner and the mother being the main caregiver (Ryan-Flood, 2009). Lesbian motherhood has been an issue for debate among feminist gender theorists. Are lesbian mothers to be viewed as a challenge to heteronormative parenthood, because motherhood is performed outside heteronormative standards (Clarke, 2005)? Or do lesbian mothers assimilate the 'deviant lesbian' to traditional notions of femininity, because motherhood is a generally excepted commitment for women, seen as their natural mission (Kawash, 2011)? Or both?

In the heteronormative family ideal, the female partner gives birth to all children while the male partner does not give birth. A lesbian family has a different situation when having a child, because both the birth-giving and the non-birth-giving parent are women. Therefore, lesbian couples provide an opportunity to theorize on differences between parents that are tied to birth-giving rather than gender differences. Furthermore, if a lesbian couple has more than one child, they might choose to have one mother give birth to all children, or to switch roles for a younger sibling. These opportunities further enable theory on parental responsibilities, such as caregiving and breadwinning, to be developed. Status as birth mother and nonbirth mother, and in particular the role of a non-birth mother, is recurrently in focus for theorizing on the parental role and its relation to gender (Downing \& Goldberg, 2011; Oerton, 1997; Padavic \& Butterfield, 2011).

\section{Aims and research questions}

When the present research project was initiated, in 2009, no academic work had yet engaged with same-sex parents who had had children after the legal changes. We did not know how these parents would describe their routes to parenthood in contemporary Sweden. A research project aiming to explore this field was funded by the Swedish Council for Working Life and Social Research (Reg. no. 2008-0449) and provided the academic scope for the present 
doctoral thesis. The focus of the thesis is on families where two women share legal parenthood and custody of their children. The thesis is situated in the field of lesbian and gay family studies.

The overall aim that has guided the thesis is to provide knowledge about Swedish lesbian parenting couples and their children, during a time of legal recognition. The thesis aims to broaden our understanding of lesbian family practices, and to focus on the interplay between family members within lesbian families, and between the family members and their surroundings. Furthermore, the thesis aims to visualize and analyse notions of heteronormativity and homonormativity in contemporary Sweden. The thesis departs from the families' own points of views - thus capturing stories, reflections, descriptions and discourses formulated by the family members themselves.

Five papers address the subject, with different aspects of family life in focus. Paper I focuses on encounters with healthcare professionals. The paper engages with the question: How do lesbian parents talk about their encounters with healthcare providers prior to and during pregnancy, at childbirth and during the early stages of parenthood? Paper II deals with second-parent adoption processes and asks two questions: How do lesbian women depict the meaning and impact of second-parent adoptions in their lives? And how do they talk about their experiences of going through the adoption processes as such? Paper III brings us closer to the family members themselves and focuses on equality in parenting relations. My question is: How do the parents depict their own and their partners' roles as parents in relation to notions of equality? Paper IV focuses on encounters with fertility clinics within public healthcare, and specifically engages with deficiencies in the offered treatment. The paper asks: How do parents depict deficiencies in fertility treatment? And how do they present their ways of dealing with deficiencies? Finally, Paper V highlights the children's reflections and asks: How do children in lesbian families talk about fathers and donors? 


\section{Limitations}

Like any academic work, the present thesis has its limitations. Because the legal change in 2003 regarded both female and male same-sex couples, my interest was initially directed to both lesbian and gay male families. When recruiting participants for the studies, I soon gained informed consent from more than a hundred female couples, but only from a few male couples. At that point I decided to focus fully on the female couples. The male couples were not of less interest to me, rather the decision was made to enable more cohesive studies.

Lesbian parenting in the $21^{\text {st }}$ century could be approached from a variety of angles. Among international studies in this field, questions on lesbian families have been addressed to a wide range of participants, besides the family members themselves. Professionals working with families in different contexts as well as heterosexually identified lay people have been interviewed and surveyed about their attitudes towards or reflections on same-sex parenting (e.g. Averett \& Hegde, 2012; Becker \& Todd, 2013; Chapman, Watkins, Zappia, Combs \& Shields, 2012; Choi, Thul, Berenhaut, Suerken \& Norris, 2006; Spidsberg \& Sørlie 2012; Hegde, Averett, Parker White \& Deese, 2013; Herbstrith, Tobin, Hesson-McInnis, \& Schneider, 2013; Hollekim et al. 2012; Morse, McLaren \& McLachlan, 2007; Nicol, Chapman, Watkins, Young \& Shields, 2013). Policy documents and juridical decisions may also serve as valuable data sources (e.g. Ritenhouse, 2011; Rivers, 2010; Tobin \& McNair, 2008). Because participants in the present studies are lesbian parents and their children, information, perspectives and insights that could have been provided by other participants or data sources are not covered. However, it is the parents and their children who are most strongly affected by the changed opportunities for lesbian families. Their own perspectives on family making open up for a broad range of questions to be raised and answered. Reflections on relations between family members are most fairly addressed to the families themselves. Furthermore, parents' descriptions of encounters between them as lesbian parents and their surrounding society may provide perspectives that are concealed from the predominant heteronormative knowledge. Children with lesbian parents grow up 
with non-heterosexual role models and may acquire unique knowledge on family life and formation. Their reflections on family life are therefore of great interest.

Findings from the present thesis should not be generalized to other contexts or situations. Rather, the strength of the thesis is that it enables an understanding of family making in relation to the specific context where it takes place, i.e. among lesbian families in contemporary Sweden. 


\section{Chapter II}

\section{Previous research on lesbian parents and their children}

This chapter provides an overview of the research field of lesbian parenting, and children growing up in lesbian families. I initially describe international research in the field, and thereafter turn to the Swedish context.

\section{International research on lesbian parenting}

The present doctoral thesis contributes to the diverse and rapidly expanding research field of lesbian and gay family studies. During the past decades, lesbian, gay, bisexual, transgender and queer families, often labelled with the acronym LGBTQ families, have been the subject a large number of research projects. Studies in this field stream from different academic disciplines including sociology, psychology, social anthropology and medicine (Malmquist \& Zetterqvist Nelson, 2013). The field is heavily dominated by studies on lesbian motherhood, but studies on gay fatherhood increased during the 2000s. Still today, only a few studies have specifically focused on bisexual, transgender or queer parents. Most publications draw on studies conducted in North America, Western Europe and Australia. However, examples of studies can also be found from many other parts of the world, e.g. Slovenia (Sobočan, 2013), Japan (Arita, 2006), Israel (Ben-Ari \& Livini, 2006), Chile (Herrera, 2009) and South Africa (Lubbe, 2008).

The research field exploring lesbian families has its origins in the late 1970s and has expanded steadily thereafter (Clarke, 2008; 
Malmquist \& Zetterqvist Nelson, 2013). Early studies on lesbian parents were often initiated as a direct response to court custody cases (as described by Clarke, 2008; Connolly, 1998; Falk, 1989). In the 1970s, 80s and 90s in the United States, lesbian women lost custody of their children to their former husbands, when judges claimed that lesbians were unfit for child custody. Based on heterosexist moralism and psychoanalytical pathological views on homosexuality, it was argued that growing up with a lesbian mother would risk damaging the children's psychological health (Clarke, 2008). Children's gender identity, gender conforming behaviour and future heterosexual orientation were thought to be at stake, from a point of view where non-heterosexual and non-gender conforming behaviour were valued negatively. The first studies on lesbian parenting addressed these concerns and focused on the children's psychological outcome. In such studies psychological wellbeing, social skills, gender conformity etcetera were measured and compared to test norms or matched groups of children with heterosexually identified parents. Since one of the first initiatives to study child outcome was taken by British psychologist Susan Golombok in late 1970s (Golombok et al., 1983; Golombok, Tasker \& Murray, 1997), several others have followed suit (Bos \& van Balen, 2008; Bos, van Balen \& van den Boom, 2004; Bos \& Hakvoort, 2007; Brewaeys, Ponjaert, van Hall \& Golombok, 1997; Chan, Brooks, Raboy \& Patterson, 1998; Crouch, Waters, McNair, Power \& Davis, 2014; Flaks, Ficher, Masterpasqua \& Joseph, 1995; Gartrell et al. 1996; Gartrell, Deck, Rodas, Peyser, \& Banks, 2005; Gartrell, Rodas, Deck, Peyser, \& Banks, 2006; Goldberg, Kashy \& Smith, 2012; Shechner, Slone, Lobel, \& Shechter, 2013). Lesbian families have been examined longitudinally and contemporary outcome studies report results on offspring outcome in adolescence and early adulthood (Bos \& Gartrell 2010, 2011; Bos, Gartrell \& van Gelderen, 2013; Bos, van Gelderen \& Gartrell, 2014; Bos, Goldberg, van Gelderen \& Gartrell, 2012; Gartrell \& Bos, 2010; Gartrell, Bos \& Goldberg, 2011; Gartrell, Bos, Peyser, Deck \& Rodas, 2012; Golombok \& Badger, 2010; van Rijn-van Gelderen, Bos \& Gartrell, 2015). Overviews on this research generally state that there are more similarities than differences in child outcome between lesbian and heterosexual families (Andersen et al., 2002; Biblarz \& Stacey, 2010; Bos \& van Balen, 2010; Fedewa, Black \& Ahn, 2014). When 
differences have been found, these tend to be small and for the most part advantageous for lesbian families.

\section{Studies on lesbian family life and practices}

Following the lesbian gayby-boom in the 1990s (Weston, 1991), research on lesbian families has broadened and expanded (Clarke, 2002; Malmquist \& Zetterqvist Nelson, 2013). Besides child outcome measurements, lesbian parents have been participants in interview studies and surveys covering diverse aspects of family life and family practices. Without claims to be comprehensive, I will in this section describe some of the issues elaborated on.

Studies on decision-making processes outline different paths to parenthood for lesbian prospective mothers. A first and most pervasive decision to make is whether to become a parent or to remain child-free (Mezey, 2008; Wall, 2013). Once the decision to parent is grounded, the prospective mother(s) might consider several routs to parenthood depending on social conventions, personal preferences and values, legal access and economic resources etcetera (Mezey, 2008; see also Ryan-Flood, 2009; Wojnar \& Katzenmeyer, 2014). One route to parenthood is to apply for adoption or to have foster children (Ausbrooks \& Russel, 2011; Averett, Nalavany, \& Ryan, 2009; Brown, Smalling, Groza \& Ryan, 2009; Farr \& Patterson, 2009; Goldberg, 2009; Goldberg, Downing \& Sauck, 2007; Goldberg, Moyer, Kinkler \& Richardson, 2012; Goldberg \& Smith, 2011; Mallon, 2011; Ross et al., 2008; Ross, Epstein, Anderson, \& Eady, 2009; Ryan \& Whitlock, 2007; Woodford et al., 2010). Others choose assisted reproduction and may have donor insemination or IVF. For a couple, this path to parenthood means that the partners have to decide which of them will get pregnant (first), a choice that gives the mothers different parental roles as birth mother and non-birth mother, which must be negotiated (Abelsohn, Epstein \& Ross, 2013; Hayman, Wilkes, Halcomb, \& Jackson, 2013; Wojnar \& Katzenmeyer, 2014; see also Ryan, 2013). Donated semen could be provided through sperm banks and fertility clinics, where the donor is anonymous to the parents and the child (Chabot \& 
Ames, 2004; Donovan \& Wilson, 2008; Frith, Sawyer \& Kramer, 2012; Nordqvist, 2012, 2014; Vanfraussen, Ponjaert-Kristoffersen \& Brewaeys, 2001). Some clinics offer identify-release donors, i.e. where the offspring in adulthood has access to the donor's identity, if they so desire. Lesbians may also choose to involve a known man or a male couple in order to become pregnant. Some women collaborate with fathers in shared parental responsibilities, while others choose a known donor who is not to be involved in daily parenting (Dempsey, 2010; Donovan, 2000). An American study shows that, at 18 years after the insemination, most of their lesbian participants were satisfied with their donor choice, but mothers who had chosen anonymous donors were more often dissatisfied with their choice than mothers who had chosen known or identity-release donors (Gartrell, Bos, Goldberg, Deck \& van Rijn-van Gelderen, 2015).

In some countries, it is possible to have a fertilized oocyte from one partner transferred to the other partner after IVF treatment (Marina et al., 2010; Pelka, 2009). This path to parenthood offers shared biological parenthood for two women, with one genetic mother and one birth mother. Shared biological parenthood for partners in a lesbian couple is also possible in cases where one woman is transgender and utilizes her own semen to fertilize the partner's oocyte.

Once a child has been born or adopted, everyday caregiving and housekeeping routines must be negotiated and established. Parentchild relations and relations between parenting partners have been the subject of several studies (e.g. Berkowitz \& Ryan, 2011; Dunne, 2000; Folgerø, 2008; Tornello, Johnson \& O’Connor, 2013; Weeks et al., 2001). The shared gender of two women parenting and housekeeping together opens a space for equality and power in intimate relations to be negotiated beyond gender differences (Gabb, 2005). Only one partner has a biological tie to each child, in most lesbian families. Shared gender, but non-shared biological ties, therefore opens different family dynamics for lesbian couples compared to different-sex couples. This concerns questions of how household and parenting tasks are negotiated and divided among lesbian parents. Results have generally shown that lesbians are more 
egalitarian than different-sex couples (Bos \& van Balen, 2010; Bos, van Balen \& van den Boom, 2007; Chan et al., 1998; Ciano-Boyce \& Shelley-Sireci, 2002; Goldberg, Smith \& Perry-Jenkins, 2012a; Patterson, Sutfin \& Fulcher, 2004; Perlesz et al., 2010; Tasker \& Golombok, 1998). Still, some studies point out that the positions as birth mother and non-birth mother, respectively, tend to form divided parental roles, with the birth mother being the main caregiver and the non-birth mother the main breadwinner (Bos et al., 2007; Ciano-Boyce \& Shelley-Sireci, 2002; Downing \& Goldberg, 2011; Goldberg \& Perry-Jenkins, 2007; Patterson, 1995). Some children, in both adoptive and biologically grounded lesbian families, seem to prefer one mother to the other (Goldberg, Downing \& Sauck, 2008; Pelka, 2009). When equality and close parent-child relations are highly valued, such preferences are described to cause jealousy between the mothers. However, all parents have not experienced children's hierarchical preferences; some describe their children as liking both mothers equally or as oscillating in their preferences.

Besides the immediate family, several researchers have turned their interest to other social relations, i.e. relations to extended family, friends, colleagues, schools and neighbourhood (Almack, 2008a; Goldberg \& Smith, 2011; Oswald \& Lazarevic, 2011; Puckett, Horne, Levitt \& Reeves, 2011; Rigs \& Willing, 2013). Having a child in a planned lesbian family often directly involves healthcare services or welfare institutions, such as fertility clinics, maternal health care or adoption agencies. Accordingly, a great number of studies regard lesbians' encounters with such institutions (Brown et al., 2009; Cherguit, Burns, Pettle, \& Tasker, 2013; Dahl, Fylkesnes, Sørlie \& Malterud, 2013; Dahl Spidsberg, 2007; Goldberg et al., 2007; Goldberg, Weber, Moyer \& Shapiro, 2014; Hayman et al, 2013;; Kinkler \& Goldberg, 2011; McManus, Hunter \& Renn, 2006; Mallon, 2011; Peel, 2010; Ross et al. 2008, 2009; Ryan \& Withlock, 2007; Shields et al., 2012; Wilton \& Kaufmann, 2001). These studies generally highlight discrimination and prejudices, labelled as heteronormativity, heterosexism or homophobia, depending on the researcher's epistemological and theoretical background. Most studies in this field start from the parents' experiences, collected via interviews or surveys and then sorted thematically. Positive 
experiences of well-informed, friendly and caring others are reported alongside negative experiences where others are prejudicial against lesbians. A few publications have also highlighted how the parents deal with discrimination, either focusing on negotiation strategies to avoid deficient treatment in the concrete situation (McNair et al., 2008; Ryan \& Berkowitz, 2009; Short, 2007), or on how deficiency is smoothed over when presented in the interview situation (Lee, Taylor \& Raitt, 2011).

Previous research on lesbian family practices has had a predominant focus on the parents. However, some scholars have turned their interest directly to the children themselves, not to measure their psychological outcome, but to capture their voices. Children brought up in LGBTQ families could be described as culturally queer, i.e. they are brought up with non-heterosexual role models and learn early on to see the world from non-heteronormative perspectives (Goldberg, Kinkler, Richardson \& Downing, 2012b). The unique experiences gained by these children have been the subject of recent interview and survey studies. Experiences of openness, disclosure and stigmatization among children in LGBTQ families have been in focus in several studies (van Gelderen, Gartrell, Bos, van Rooij \& Hermanns, 2012; Gianino, Goldberg \& Lewis, 2009; Goldberg, 2007; Kuvalanka, Leslie \& Radina, 2014; Lick, Patterson \& Schmidt, 2013; Lubbe, 2008; van Rijn-van Gelderen et al., 2015; Vanfraussen, Ponjaert-Kristoffersen \& Brewaeys, 2002), and school experiences among these children have been scrutinized specifically by some researchers (Epstein, Idems \& Schwartz, 2013; Streib-Brziĉ \& Quadflied, 2012, see also Malmquist, Gustavson \& Schmitt, 2013). Another explored issue deals with images of and curiosity about unknown sperm donors (Goldberg \& Allen, 2013a; Jadva, Freeman, Kramer \& Golombok, 2010; Scheib, Riordan \& Rubin, 2005; Vanfraussen, Ponjaert-Kristoffersen, Brewaeys, 2003). While some adolescents and young adults express no interest in their donor's identity, others are curious about this person and desire more information (Vanfraussen et al., 2003). A growing American-based registry enables offspring and parents to search for anonymous sperm donors or biological half-siblings who share the same donor (Beeson, Jennings \& Kramer, 2011; Jadva et al., 2010). Researchers surveying the registry report that those who have found their donor 
or donor siblings tend to keep in touch and describe positive relations. Other issues focused on in interviews with youth and young adults in LGBTQ families concern their relations to the LGBTQ community (Goldberg et al., 2012b), relations to parents after a parental divorce (Goldberg \& Allen, 2013b), and views on marriage for oneself when the parents are not allowed to marry (Goldberg, 2014). Most of the studies on children in LGBTQ families include adolescents and/or young adults as their participants, while interview studies with younger children are still rare. One exception is the work by Fiona Tasker and Julia Granville (2011), who interviewed children in the UK, aged between 4 and 11 years, on who they included in their families, and showed that children and parents concur in how they describe their families.

\section{Debating the research field}

The research field on lesbian and gay parenting has been the subject of academic debate. American sociologists Judith Stacey and Timothy Biblarz (2001) raised critique against child outcome studies, stating that scholars have mitigated differences between family forms in fear of negative legal decisions for lesbian parents. Their contribution was in turn criticized by other scholars. Sociologist Stephen Hicks (2005) frankly questioned the claims by Stacey and Biblarz, while psychologist Victoria Clarke (2002, 2008) describes outcome studies as constituting a specific era in the research field, induced by court custody cases. More recently, some empirical studies have questioned the methodological rigor of the outcome studies, where no differences between same-sex and different-sex families are generally claimed, and have provided randomized data on larger samples to show that differences are present and that same-sex families come out as deficient (Potter, 2012; Regnerus, 2012). Those differences are, however, generally explained by transitions in family structure, such as divorces, as most same-sex families in the studies have been formed after a previous separation in a different-sex couple. When number of transitions is statistically controlled for, the differences tend to disappear (Potter, 2012). 


\section{Research on lesbian families in Sweden}

\section{Studies prior to legal recognition}

Only a few empirical studies have dealt with lesbian parent families in Sweden. The earliest studies were initiated shortly before the turn of the millennium, when the Swedish Government commissioned an inquiry to investigate outcomes among children in same-sex families (SOU 2001:10). At that time, same-sex couples were not allowed to share legal parenthood or child custody; they could not apply for adoption and were excluded from assisted reproduction. Besides reviewing international research in the field, the inquiry group assigned researchers at two Swedish universities to investigate conditions for children with Swedish lesbian and gay parents. The first study, conducted as a Master's thesis by psychologist Katarina Malmström, focused on younger children and employed psychological assessment tools to investigate how the children viewed themselves, their close family and their peers. Results showed that the children had higher self-confidence than the test norm, with good peer relations and social skills. The second study, conducted by psychologist and researcher Karin Zetterqvist Nelson, reported findings from interviews with adolescents and young adults with lesbian mothers and gay fathers. The results showed that most interviewees had positive relations with their lesbian or gay parent, but several had faced temporary issues with friends owing to prejudices against their parents' sexual orientation. Both studies were published in the official report, SOU 2001:10, where the investigators finally concluded: "The overall research shows that children with homosexual parents have developed psychologically and socially in a similar manner as the children they were compared with" (SOU 2001:10, p. 15). This conclusion led the committee to suggest that registered partners should be permitted to apply for adoption and second-parent adoption, and that lesbian women should gain access to assisted reproduction treatment. The law was changed accordingly in 2003 (Proposition 2001/02:123) and 2005 (Proposition 2004/05:137).

Only a couple of years prior to these legal changes, two different research projects on lesbian parenting were initiated. Zetterqvist 
Nelson and her colleagues conducted an interview study with parents in planned LGB families (Zetterqvist Nelson, 2006; 2007). Most of the interviewees were engaged in shared parenting between lesbians and gay men, who had conceived together through self-insemination. Zetterqvist Nelson (2007) describes their narratives as success stories from a pioneer generation of LGB parents who overcame extensive obstacles to become parents. Because only one partner in a same-sex relationship could be legally recognized as the child's parent, relations between children and their non-biological parent(s) were vulnerable. In several families, lesbian and gay shared parenthood, where children lived in two households with three or four parents, had led to conflicts (Zetterqvist Nelson, 2006). Despite initial agreements on shared responsibility, some fathers depicted their children's mothers as unwilling to let them be equally involved in daily caretaking. Besides sharing parenting with men, some lesbian women also turned to fertility clinics abroad (Zetterqvist Nelson, 2007). Most interviewees, however, claimed that shared parenting with gay men was preferred over visiting fertility clinics.

The second study, conducted at the same time, was performed by Ryan-Flood (2005, 2009). Ryan-Flood's work is a comparative study on lesbian parenting in Sweden and Ireland. Like in Zetterqvist Nelsons study, most of Ryan-Flood's Swedish lesbian participants were involved in shared parenting with gay men. The Irish couples, however, had mainly chosen to parent on their own, stating that an active father would interfere with the non-birth mother's parental role. The three-/four-parent unit was described as a typical Swedish homosexual family form, understood in relation to a Swedish norm where caregiving fathers are highly valued.

\section{Studies in a time of legal recognition}

Besides the present research project, some other empirical studies have dealt with Swedish lesbian families since the legislative change enabled shared legal parenthood. These are three studies focusing on parental experiences of health and healthcare and two studies dealing with social experiences of daughters and sons in LGBTQ families. 
In a small interview study, nurses Anna-Karin Larsson and AnnaKarin Dykes (2008) explore lesbian women's experiences of healthcare during pregnancy and childbirth. In general, their interviewees had positive experiences of care and highlighted openness as important for the positive encounters. The participants also raised critique against the parent education courses arranged within maternal healthcare, where different-sex couples are in focus and other family forms are overlooked. Larsson and Dykes' interviews were conducted in 2003, when lesbian couples had recently been granted access to shared legal parenthood, but were still denied fertility treatment in public healthcare. The legal changes are mentioned in their article, but the findings are not interpreted in relation to the legal situation.

Additionally, one small interview study was conducted by nurse Gerd Röndahl and her colleagues (Röndahl, Bruhner \& Lindhe, 2009). Their study deals with lesbian parents' experiences of encounters with professionals in healthcare during pregnancy and childbirth, as part of a larger study on lesbians' and gay men's experiences of healthcare (see Röndahl, 2005). Röndahl and her colleagues (2009) show that most of their participants reported positive experiences of professionals in reproductive healthcare. However, the participants often presented negative experiences as resulting from bad personal chemistry rather than structural prejudices, thus structural heteronormativity was mitigated by the interviewees. The interviews were conducted in 2008, but it is not mentioned whether these parents had had their children prior to or after the legal changes.

A study that departs from lesbian couples' access to fertility treatment is midwife Catrin Borneskog's doctoral thesis (2013). Borneskog compares psychological health, relationship quality and parenting stress in lesbian and heterosexual couples during and after assisted reproduction treatment in public healthcare. Based on surveys with more than 800 participants, she concludes that the lesbian couples had lower levels of parental stress and higher relationship satisfaction than the heterosexual participants did. The lesbian couples reported low levels of depression and anxiety prior to, during and after treatment. 
School experiences among children in LGBTQ families were in focus in ethnologists Malena Gustavson and Irina Schmitt's interview study (Gustavson \& Schmitt, 2011). Through interviews with children, adolescents, parents and field experts, the researchers concluded that children and adolescents apply a range of strategies to deal with the heteronormativity encountered in schools. However, most of the interviewees had predominantly positive school experiences, with only a few reports on bullying. Within the study, the researchers also produced pedagogical material on LGBTQ families.

Doctoral student in child and youth studies Per Nordén focuses in an ongoing research project on adolescents and adults who grew up with LGBT parents (Institutionen för pedagogik, kommunikation och lärande, 2012). Narratives on family life, school experiences and leisure time are collected through interviews.

\section{Other studies within the present research project}

Besides the present doctoral thesis, some smaller studies have been conducted as part of the same research project, and will be overviewed here.

In his Master's thesis in psychology, Alexander Rozental contributes to knowledge on lesbian women who have conceived through assisted reproduction within Swedish public healthcare (Rozental, 2011). This work was supervised by Zetterqvist Nelson and myself, and the study was designed in collaboration between Rozental and us. The study builds on interviews with 19 women in ten families. Rozental shows how these women account for their chosen path to parenthood, by describing public healthcare as safe and secure, and by highlighting the advantage of the simpler process of obtaining legal parenthood for the non-birth mother that is granted women in public fertility treatment only. Furthermore, the interviewees highlight the advantage of tax-funded treatment and of being able to visit a nearby clinic. Paper IV in the present thesis draws partly on Rozental's interviews, and analyses how interviewees depict actual 
encounters with the healthcare system during their treatment processes.

A second Master's thesis in psychology, conducted within the present research project, was written by Anna Möllerstrand and Maria Wikström (2011). Their thesis was also supervised by Zetterqvist Nelson and myself, and the study was designed in collaboration with the Master's students. This study draws on interviews with twelve young children in lesbian families, showing how they talk about their families and child conception. The children talk about families in terms of emotional and physical closeness, like "you take care of each other" and "it's people who live together". Mothers are generally depicted as caregivers. For the most part, the interviewees' descriptions correspond well with how other children have described families and mothers in previous studies. When talking about fathers, however, these children differ from children in previous research. When working with Paper V in the present thesis, I conducted a detailed analysis of how the children discuss donors and fathers.

A final Master's thesis in psychology also deals with notions of donors and fathers, and was written by Anna Polski (2013) and supervised by Eva Brodin and me. Polski's study draws on interviews with eleven lesbian mothers in seven families, and shows their perspectives on questions concerning donor conception and biological ties, when children have been conceived with help from anonymous sperm donors. The interviewees mainly depict the donor as a non-parent, and construe him as unimportant to them. At the same time, the donor is described as the child's other genetic half, and the mothers rhetorically deal with discourses where genetic origin is seen as crucial to the child's identity. Departing from Polski's study, I have added empirical data from my own interviews with lesbian mothers, where anonymous sperm donation is discussed (Malmquist, Polski \& Zetterqvist Nelson, forthcoming). Their accounts are analysed in relation to a discourse on 'the good parenthood' in a joint forthcoming publication.

In a Bachelor's thesis, Maria Bergqvist (forthcoming) analyses adoption protocols from second-parent adoptions in lesbian families, 
along with social workers' assessments of the adopter. This study builds on data that I have collected for the present research project, and the study is supervised by Jessica Sjögren me. Bergqvist shows a difference between how the parents and the social workers depict the adoption in the protocols. While parents depict themselves as being a family already, and apply for the adoption in order to have their family legally recognized, social workers tend to depict the adoption as crucial for them to become a family.

In a forthcoming publication (Malmquist, forthcoming), I describe how lesbian women arrange parental leave, and how they account for their arrangements in interviews. By far the most common arrangement was that both parents took long parental leaves, organized so that the birth mother stayed home the first period, and switched with the non-birth mother when the birth mother returned to work. I call this the homonormative arrangement. Those parents often argue for the importance of equality, both for developing equally close parent-child relationships and for creating an equal relationship between the parents. A smaller group of interviewees had a much more uneven arrangement of parental leave, where the birth mother had taken all or almost all time off work. I denominate this the heteronormative arrangement. Interestingly, those parents also relate to the equality discourse, but justify their unequal shares with reference to the non-birth mother's work benefits or work demands. Finally, another small group of parents found other forms of arrangements, where both mothers stayed home from early on, and alternated the caretaking of the child. I call this the un-normative arrangement. This arrangement challenges the claimed equality in the homonormative arrangement, where the stay-home order between the parents is fixed and provides different situations for birth mothers and non-birth mothers during the child's infancy.

Swedish legislation on same-sex parents has been discussed in two publications connected to the present research project. Zetterqvist Nelson and I discuss, in a book chapter, the inclusion of lesbian couples in public fertility programmes (Zetterqvist Nelson \& Malmquist, 2011). When the legislative change in 2005 gave lesbian couples access to fertility treatment within public healthcare, this inclusion must first and foremost be regarded as a positive result of 
gay and lesbian activism. Options for lesbian prospective parents had broadened and a lesbian couple was officially recognized as a sufficient family that deserved public healthcare in order to become pregnant. The legal opening could, however, also be interpreted as reflecting heteronormative and restrictive politics. Sweden has a long tradition of identity-release donors for different-sex couples, where the children conceived through gamete donation are granted access to the donors' identity once adult. Unlike many other countries, anonymous sperm donation to clinics is forbidden by law in Sweden. When lesbian couples gained access to fertility treatment, an argument for the inclusion, presented in the proposition (2004/05:137), was to prohibit the practice of lesbians conceiving with anonymous donors abroad. By giving lesbian couples access to fertility treatment with identity-release donors, state authorities could maintain their control over and registration of the children's genetic origins.

In a research article, Kristin Zeiler and I discuss a legislative restriction in Sweden that hinders lesbian couples from having children where one mother provides the oocyte and the other carries the pregnancy (Zeiler \& Malmquist, 2014). IVF with Reception of Oocytes from Partners (ROPA) could be desired for medical reasons, when one woman has no or a non-functioning uterus, or when one woman has no or non-sufficient eggs. ROPA could also be desired when one partner wants to be the genetic parent but does not wish to become pregnant, or when the couple has spare embryos from a previous IVF treatment and wishes to switch birth mother for the next child. ROPA is currently forbidden in Sweden, because it is considered a form of embryo donation, which in turn is forbidden. In the article, we show that the law is heteronormatively biased. While a woman partnered with a man is allowed to have IVF treatment with an embryo created by gametes from her partner and a donor, a woman partnered with another woman is not allowed to have IVF treatment with an embryo created from gametes from her partner and a donor. 


\section{Chapter III}

\section{Methodology}

In this chapter, I describe my epistemological point of departure and the analytical approaches employed in the empirical studies.

\section{Social constructionism and post-structuralism}

This work relies on a social constructionist epistemology. A social constructionist perspective highlights that knowledge and experiences are situated historically and culturally (Burr, 2003). How people capture and understand what they experience does not simply reflect a 'reality', but is rather highly dependent on their available categories, which are construed through previous knowledge and cultural context. How knowledge is shared and discussed is also highly dependent on language and social interaction. A narrative or a statement must therefore always be interpreted and understood in its cultural context. Unlike how positivist epistemology assumes that there is an actual 'truth' or 'reality' that can be described through accurate observation, the social constructivist researcher claims that there are different 'truths' in different contexts or perspectives.

Social scientists from disciplines like philosophy, history and sociology made a 'turn to language' from the 1950s and onwards (Willig, 2008). Leaving behind a structuralist understanding of language as fixed and stable, scholars drew attention to the temporary and sometimes contradictory relations between words and objects. The new post-structuralist view acknowledged language as socially performative and productive. Furthermore, language was 
said to be structured in meaning systems or discourses. Psychologists' turn to language came about much later, during the 1980s (see Henriques, Hollway, Urwin, Venn \& Walkerdine, 1984; Potter \& Wetherell, 1987). In psychology, language has long been viewed as a representation of cognition, a point of departure still applied in mainstream psychology. People's claims are usually seen as a reflection of their attitudes or opinions. Within the 'turn to language' such an understanding of was challenged, and discursive interpretations of talk and interaction developed within psychology.

\section{Discursive psychology}

Discourse analysis is an umbrella term that covers a broad, multifaceted and sometimes contradictory collection of research methods and theory. One form of discourse analysis is discursive psychology, where talk-in-interaction is utilized to analyse the negotiation of psychological phenomena such as identity or dilemmas (Edely, 2001; Edwards \& Potter, 1992). Rather than seeing talk as a simple reflection of someone's thoughts or knowledge, a discursive psychologist shows how any statement is expressed in a specific context, and formed by the speaker's momentary stake and interest. Close attention is paid to how a speaker uses language in social interaction to present an opinion and avert any negative evaluations (Potter \& Wetherell, 1987). For example, in a comprehensive study, social psychologists and discourse analysts Margaret Wetherell and Jonathan Potter (1992) outline how racism is discursively dealt with among their New Zealander interviewees. Rather than considering racism to be a cognitive feature (like a personal attitude), Wetherell and Potter show how racism is construed, as the interviewees justify themselves in the interviews. Likewise, in another work, Potter and his colleague Susan Speer show how heterosexist talk is performed in interaction rather than reflecting 'homophobic' attitudes (Speer \& Potter, 2000).

Since its birth in the 1980s, discursive psychology has come to grow in different directions when further developed by different scholars. Some discursive psychologists are highly inspired by conversation 
analysis and conduct a discourse analysis that in detail focuses on the micro-units in interaction (see Kitzinger, 2006; 2009; Potter, 2012a, 2012b). Others have moved closer to Foucauldian discourse analysis (see Edley, 2001; Wetherell, 1998, 2007), which starts from the works of Foucault and his outlining of the relationship between knowledge, language and subjectivity (Foucault, 1972). The Foucauldian discourse analyst, sometimes labelled a 'critical' discourse analyst, is concerned with identifying and describing the different discourses available in a specific context and the power resources connected to these discourses. Attention is paid to the effect that discourse has on the subject in focus (see Henriques et al., 1984/1998). Wetherell has, together with Nigel Edley (Edley, 2001; Wetherell, 1998, 2007), construed a synthesis, a critical discursive psychology that embraces both discursive psychology's focus on communication and argument as social actions and critical discourse analysis' focus on power relations and subjectivities.

A discourse analytical approach suited the aims of Paper I and III well, where I engaged in detail with interview talk. The analyses mainly focus on the rhetorical and communicative dimensions of the interview talk, thus on aspects that are central in discursive psychology. When the rhetorical aspects of speech are the focus of analysis, the broader context is less visible. However, the findings are also discussed in relation to heteronormativity in contemporary Sweden, thus contextual power relations are acknowledged.

Three concepts have been central to the analysis: interpretative repertoires, subject positions and accounts.

Discourse analysts interested in how discursive resources are used by a speaker in a particular context sometimes prefer to talk about interpretative repertoires rather than discourses (see Edley, 2001; Wetherell \& Potter, 1992). An interpretative repertoire is defined by Wetherell as "a culturally familiar and habitual line of argument comprised of recognizable themes, common places and tropes" (Wetherell, 1998, p. 400). When people draw on a specific interpretative repertoire, they use terms, images and metaphors adjusted to the specific context. Potter and Wetherell (1987) show that one and the same repertoire can be drawn on by members of 
different groups or categories. Likewise, a speaker may draw on different, or even contradictory, repertoires as she or he talks. They explain:

\begin{abstract}
'[T] here is no attempt in discourse analysis to find consensus in the use of repertoires in the sense that some people are found to always use a certain repertoire, and certain people another. Interpretative repertoires are used to perform different sorts of accounting tasks. Because people go through life faced with an ever-changing kaleidoscope of situations, they will need to draw upon very different repertoires to suit the needs at hand. From this theoretical perspective what is predicted is exactly variability rather than consensus.' (Potter \& Wetherell, 1987, p. 156)
\end{abstract}

In the detailed analysis of discursive psychology, a speaker may appear incongruent when drawing on contradictory repertoires. However, a closer look at the responses in a dialogue may demonstrate how such talk appears to be self-evident from the listener's point of view.

Subject positions are closely related to interpretative repertoires (Edley, 2001). Subject positions are located within the repertoires in terms of the 'I', 'we' or 'they' that are construed in the talk. When identifying and analysing subject positions, the researcher looks at how people depict themselves in the story, and what identities they work up. Also, the researcher draws attention to how 'others' are depicted in interaction. If a lesbian mother claims that she and her partner have no stereotypical gender roles and therefore are able to form an equal relationship, she is building up an identity for herself and her partner as 'equals'. At the same time, she is contrasting their relationship to something else, the others that are positioned as 'stereotypical' or 'unequal'.

Another central concept for discursive psychologists is accounts (Edwards \& Potter, 1992; for an early outline of the concept, see Scott \& Lyman, 1968). In order to validate a statement, the speaker may employ a series of accounts, such as excuses, justifications, apologies, defences, explanations and narratives (Buttny, 1993). For instance, claiming that "I'm not homophobic, but..", would rhetorically serve to justify further homophobic statements. A careful analysis of such discursive components conveys assumed 
normative values and standards to which the speaker is relating. Furthermore, rhetorical strategies may serve the speaker in the construction of an account as factual, with the effect that it appears as external to her- or himself (Edwards \& Potter, 1992; Potter, 1996). To increase the perceptive veracity of their claims, people present statements as if they represented objective features or truths, rather than their own desires and interests. Thus, analysing how accountability is construed in a specific context is an analytical task for the discursive psychologist. Derek Edwards has, together with Potter, listed common discursive strategies that are drawn on when something is at stake for the speaker (Edwards \& Potter, 1992). Some of these strategies have been useful in my analysis and will be presented in the papers.

\section{Thematic analysis}

A thematic analysis is a foundational method in qualitative research (Braun \& Clarke, 2006, 2013; Howitt, 2010), and the empirical data in Paper II, IV and V have been analysed using such a method. A thematic analysis could be performed as an initial step before further qualitative analysis is conducted, or "be considered as a method in its own right" (Braun \& Clarke, 2006, p. 78). The core aim of a thematic analysis is to identify and analyse patterns in qualitative data, such as interview material. A theme in thematic analysis is basically a pattern in the dataset. In their guide to thematic analysis in psychology, Virginia Braun and Victoria Clarke (2013) liken a theme to a wall or roof panel of a house. The wall is in turn built by a large number of bricks - the many individual ideas that in the analysis are identified as 'codes'. Themes have different characteristics in different analyses. Braun and Clarke (2006) differentiate between semantic and latent themes, where semantic themes are rather explicitly identified in the data and latent themes require an interpretation of the meaning or impact of the pattern.

Unlike discourse analysis, which is closely tied to social constructionism, thematic analysis is not in itself bound to any epistemological paradigm (Braun \& Clarke, 2013). In the present 
work, however, social constructionism has been the point of departure for all thematic analyses. Braun and Clarke (2006) argue that what essentially is a thematic analysis is often presented as something else, for example a discourse analysis. It is, however, not always easy to separate the methods from one another. When the analysis is conducted within a social constructionist epistemology, i.e. when patterns are understood as socially construed, there is a clear connection (and possibly an overlap) between the methods. What has been named a 'thematic discourse analysis' is an analysis of themes situated in the social constructionist perspective, but where the discourse per se is not analysed. A theme in this form of analysis is not easily separable from an interpretative repertoire in a discourse analysis. However, the interpretative repertoire will engage more in detail with the performative dimension of talk, i.e. showing what the speakers do with their claims. The thematic analyses conducted in the present work are wider than the discourse analyses, which in turn focus more on details. While the thematic analyses could be described as global, i.e. capturing a large amount of data, the discourse analyses are local, i.e. engaging with rhetoric in detail. The thematic analyses therefore allow one to capture a breadth of reflections and aspects of the topic in focus. This method suited the aims of Paper II, IV and V well, because the topics in these papers have previously been understudied. 


\section{Chapter IV}

\section{The studies: Participants and procedure}

Families where two women share legal parenthood of young children have been included in the present studies. When approaching the field, I wished to get a picture of how many female couples with shared legal parenthood there were in Sweden. In this section, I explain the procedure carried out in order to get such a picture, and present descriptive data on this group. This is followed by a description of the procedure used when contacting interviewees and more detailed information on the participants. I also show how the interviews were carried out, transcribed and analysed. Finally, ethical and methodological considerations are discussed.

\section{Female couples with shared legal parenthood in Sweden}

Judicially, there are three possible pathways to shared legal parenthood for female couples in Sweden. First, a married couple, regardless of gender, may apply for adoption together (SFS 1949:381). Joint adoption, however, is as yet only a formal right with very limited opportunities for same-sex couples to adopt in actual practice (Ottosson, 2015, 26 January). Second, if one partner is already the biological or adoptive parent of a child, her spouse may apply for second-parent adoption. This is the path to legal parenthood for non-birth mothers in families who conceive at fertility clinics abroad or after self-insemination. Third, when conceiving through assisted reproduction at public fertility clinics in Sweden, both mothers are granted legal parenthood through their 
written consent (SFS 2006:351). In those cases no adoption process is required.

Treatments at public fertility clinics are registered at the clinics, and second-parent adoptions are registered at district courts. To get an overview of the number of families with two female legal parents, both district courts and fertility clinics were contacted.

\section{Second-parent adoption families}

An adoption decision, including personal data on adopter and adoptee, is public information, available at the specific district court that handled the case. Initially, in 2009, I contacted all 49 district courts in Sweden. My aim was to identify and count all female samesex second-parent adoptions carried out between February 12003 (when second parent-adoption was legally granted for same-sex couples) and February 1 2009. Despite the open access, collecting adoption decisions turned out to be a complicated and timeconsuming procedure. Each court registers all adoption errands in its own separate archive databases, but the data system does not filter adoptions in same-sex families from other adoptions. In most cases, only the specific protocol over each adoption decision would establish whether the adopter lives in a same-sex relationship or not; hence a large number of archive files must be opened in order to find all same-sex families.

Twenty-one courts had not handled any same-sex second-parent adoptions at all during the time of interest, but 28 courts had. In some smaller courts, administrators were willing to provide me a copy of all adoption decisions of interest. From most courts, I was instead provided a list of all adoption errands during the time frame. Such lists give the names of the adopter or adopters. Therefore, I could sort out second-parent adoptions (with one adopter) from joint adoptions (with two adopters). Thereafter, I returned to the court administrator with a reduced list and requested a copy of the decision protocols for the remaining errands. In some of the largest courts, where the total number of adoption decisions during the time of 
interest could exceed a thousand, crossing out joint adoptions was not enough. The remaining lists were still too comprehensive to request a copy of all errands. Each court has a public computer where some information on errands is accessible. I spent many hours at those court computers searching for information that would reveal which cases matched my target group and which did not. Finally, the lists of adoption errands were reduced to manageable sizes and I requested a copy of each decision protocol for the remaining errands. All decision protocols for same-sex second-parent adoptions were counted and descriptive data about the families were noted.

A total number of 185 unique lesbian families were found, where at least one child had been born between 2003 and 2009, and the adoption had been established before February 1 2009. In these families one, two or three children had been adopted by the non-birth mother of each child. When later scrutinizing the protocols in detail, I found some cases where second-parent adoption of an older sibling is mentioned in the protocol, but where the sibling's adoption protocol is not in the dataset. I therefore realize that some same-sex adoption cases must have been mistakably sorted out, when the huge number of errands were reviewed by myself and court administrators. The process was, however, systematic and careful, and included all district courts. Therefore, I do believe that the number of identified same-sex families gives an approximate picture of the number of lesbian families that went through the process during the time frame.

The children in the second-parent adoption families were on an average 10 months old when the adoption was established. The age of the children differs, with the youngest being 2 months and the oldest being nearly four years of age, and $18 \%$ of the children were over one year old when the adoptions were established. The parents mean age was 35 years for adopters and 34 years for birth mothers, at the time of childbirth. The parents' age ranged from 22 years to 55 years. Families who had turned to a fertility clinic abroad seem to by far outnumber those who utilized a known donor, but most protocols do not reveal how the child was conceived. 
The geographical spread of the lesbian families' second-parent adoptions is uneven across the country. Stockholm, including its suburban areas, stands for almost half, $49 \%$, of the adoption protocols. The same area is inhabited by $22 \%$ of the entire Swedish population (Statistiska centralbyrån, 2013). In relation to number of inhabitants, the lesbian adoptions are thereby largely overrepresented in this region. Adoptions are also high in frequency in the city areas of Gothenburg, Malmö and Uppsala. Those areas stand for a total of $26 \%$ of all found adoptions, while the remaining $25 \%$ were found in smaller districts courts, mainly in the central and southern parts of Sweden. In northern Sweden, only very few adoptions were found on the whole.

\section{Public fertility clinic families}

Only fertility clinics with a specific authorization are permitted to handle donated gametes in Sweden. In total, seven clinics have such authorization, and are thereby the only clinics accessible for lesbian couples. Those clinics were contacted in 2010 by Rozental (see Rozental, 2011). Rozental's data show that 568 lesbian couples had been involved in treatment at these clinics between July 12005 (when lesbians gained access to the clinics) and December 312009. On average, 126 lesbian couples per year were involved in treatment at these clinics. Rozental's data do not tell us how many of these women actually got pregnant due to the treatment and eventually gave birth. Borneskog's thesis (2013) shows that the pregnancy rate is high in lesbian couples undergoing fertility treatment within public healthcare. In her comprehensive study, $72.6 \%$ of the lesbian women in treatment gave birth due to the treatment. Based on Borneskog's statistics, a reasonable estimate is that around 90 lesbian couples each year had children after fertility treatment in public healthcare, during this time period. 


\section{Preferred paths to parenthood}

The number of lesbian couples having children through public healthcare each year (around 90) seems to outnumber by far couples who conceive elsewhere and go through a second parent adoption for the non-birth mother to become a legal parent (around 31 per year). This is not to say that public fertility treatment surely is the most common path to parenthood among contemporary lesbian couples. A couple who conceive outside public healthcare may skip or postpone the second-parent adoption, and would not be included in the calculations above. Also, when a lesbian couple share parenting with a male friend, or two men in a couple, the biological father often keeps his status as legal parent. As a child can only have two legal parents in Sweden, second-parent adoption is less likely to be conducted in such families. Families where a lesbian couple have a child together, but do not share legal parenthood, are not visible in the present data. Thus, to gain a more comprehensive and reliable picture of lesbian couples' preferred and actual paths to parenthood, other research methods would be required.

\section{Interviewees and interviews in the present study}

In this section, I share descriptive data on the participants in the present study: the interviewed lesbian parents and children. I also describe how the interviews were performed and analysed. Initially the procedure used to contact interviewees is outlined.

\section{Procedure to contact interviewees}

A figure visualizing the recruitment process is presented on page 36 . Because second-parent adoption decisions reveal personal data such as names, addresses and the personal identification numbers of adopters and adoptees, the families found in the adoption decisions 
Figure 1.

\section{Participants}

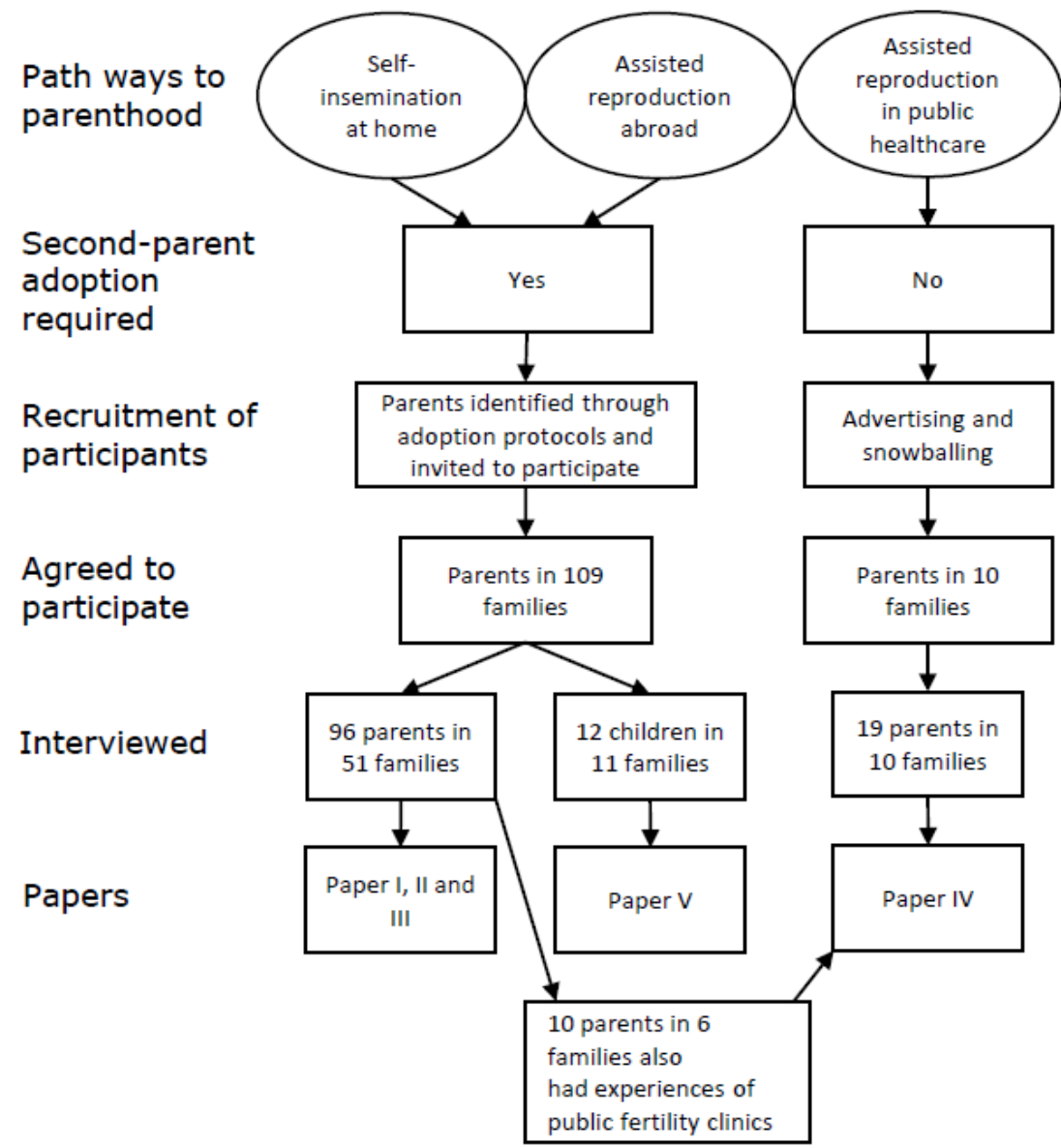


could easily be contacted. Once an adoption decision for a same-sex family had been found, the parents were contacted by printed mail and asked if they would be interested in participating in the study. The invitation letter included information about the study and the planned interviews. It also declared that participation was voluntary and that the participants could withdraw their consent at any time. All letters also contained a reply envelope and a form where consent to further contact could be signed. Once the invitation letters had been posted, all information that could identify individuals was crossed out from the collected adoption decisions and additional descriptive data could only be compiled anonymously from those documents. The procedure of contacting potential participants from adoption decisions was supported by the Regional Ethical Review Board at Linköping University (Reg. No. 165-09).

Parents in a total of 181 families were invited to participate, ${ }^{1}$ and 109 returned a positive reply. All replies were answered, but due to the large number of interested parents, not all could be interviewed. When selecting interviewees among the potential participants, I aimed to ensure a geographical spread over Sweden. Time and location for the interviews were set over the telephone. During 2009 and 2010, I conducted interviews with parents in 51 of the families that had replied indicating their interest in participating. Paper I, II and III present findings from these interviews.

Paper IV deals with encounters with public fertility clinics in Sweden. As described earlier, families who conceive through public healthcare are enabled shared legal parenthood without the process of a second-parent adoption. Therefore, all families found through their adoption protocols had had children conceived outside public healthcare. However, among the 51 families that I had interviewed, three couples had initiated their process for having children in public healthcare, before eventually conceiving elsewhere. Additionally three couples had had one child through public healthcare, besides

\footnotetext{
${ }^{1}$ From the 185 families identified in adoption decisions, my own family and a few families with personal relations to me were excluded when invitations for participation were sent out.
} 
also having one child who had been conceived elsewhere and been second-parent adopted. The interviews with parents in those six families were included in the analysis for Paper IV. To increase the number of participants for Paper IV, other methods of recruiting participants were required. Rozental sent out invitations for participation on social networks and through the Swedish Federation for Lesbian, Gay, Bisexual and Transgender Rights (RFSL). Participants were also contacted through snowballing. Parents in additionally 10 families, all of whom had conceived through public healthcare, were interviewed by Rozental. Paper IV draws on findings from both Rozental's and my own interviews, with parents in a total of 16 families.

Among the families that had responded to the initial invitation for the study, but had not yet been interviewed, nineteen families were asked to participate in the child interview study. Parents in those families were contacted over the telephone, where I explained that the study had been expanded to include child interviews as well. If they seemed positive, they received a separate invitation letter for this study directed to the parents and a letter explaining the study in simple language for the children. Children in eleven of those families were interviewed in 2011 by Möllerstrand and Wikström. Paper V builds on those child interviews.

Some of the parents who responded to the original invitation have later participated in student Master's and Bachelor's theses connected to the research project (see Polski, 2013; Bergqvist, forthcoming).

\section{Participants and interviews in Paper I, II and III}

Interviewees in Paper I, II and III were 96 parents from a total of 51 families. In 45 interviews both parents participated and were interviewed together as a couple. For the remaining six interviews, only one mother participated due to practical circumstances like conflicting schedules, or when the parents had divorced. In one of those families a new partner also participated during the entire 
interview, and in a few additional interviews other family members joined for a short while. Toddlers and infants were also present during several interviews. The following description of the interviewees includes only the 96 parents.

All interviewees parented one or two children conceived within lesbian relationships. Twenty-six couples had two children together. Twenty-five couples had one child together, but three of those families also included children from previous relationships; hence altogether 29 families had more than one child. In 19 of the families with more than one child, both mothers had given birth, while in the remaining 10 families one mother had given birth to all children. At the time of the interviews, all children conceived within the interviewees' lesbian relationships were between infancy and 10 years of age, with at least one child per family born between 2003 and 2009. Most of the couples (42) had conceived at fertility clinics with anonymous or identity-release donors. A smaller group (eight) had conceived through self-insemination with friends or acquaintances as donors or fathers with no legal custody. One family had used both conception methods, one for each child. A vast majority of families with two children had the same donor or father for both siblings, and additionally some families had wished for the same donor or father, but had not been able to conceive in accordance with their preferences. All of the lesbian couples shared custody and legal parenthood of the children conceived together (except for a few cases in which second-parent adoption of the youngest sibling had not yet been legally granted). Because secondparent adoption in Sweden is available only for married spouses and registered partners, all of the couples were married/registered partners at the time of the adoptions. At the time of the interview, a handful of interviewees had divorced the other parent.

Most of the families (36) lived in city areas or suburbs. Eleven families lived in middle size or small towns, and four families were settled in rural areas. Most interviewees were born in Sweden, while a minority had migrated from other European countries at some point in their lives. A vast majority of the interviewees were employed at the time of the interview, while a handful ran their own companies. A few interviewees were currently on parental leave, unemployed or 
on long-term sick leave. Two thirds of the mothers had university exams, while the remaining had upper secondary exams. In Sweden, both legal parents are granted 240 days of paid parental leave each, where all but 60 days are transferable to the other parent. In more than half of the interviewed families, parental leave was split equally or roughly equally between the mothers. In about one third of the families, both parents had taken long parental leaves, but the birth mother had taken out significantly more than the non-birth mother. Typically in those families, the birth mother stayed home for the first year and non-birth mother for the following half year. In only a handful of families had the non-birth mother been on parental leave for a quarter of a year or less. In a handful of families, both mothers had been home together because of one partner's unemployment or long-term sick leave.

Despite the fact that all interviewees had at least one child born between 2003 and 2009, the age of the mothers themselves differ significantly. The oldest among the interviewees are born in early $1950 \mathrm{~s}$ and the youngest in the mid-1980s. Mean age at the time of the interview was 36 years. In families with two birth mothers, the older partner had given birth to the oldest child and the younger to the youngest child. Among the families with one child, several families planned for a second child, commonly to be carried by the younger spouse.

The interviews followed a semi-structured interview guide (Howitt, 2010). All interviewees were asked to share their family narrative, describing their family life from the time when the couple had first met, until the time of the interview. During the interviews, I added questions and reflections, but several participants created their narrative with only scanty input from me. The collected interviews included reflections on a wide range of topics, like decision-making processes, intimate relations, meaning of biological bonds, pregnancy and child birth experiences, coming out processes, relations to extended family and friends, encounters with healthcare professionals, experiences of second-parent adoption and the everyday joys and challenges of parenting infants and preschool children. Some of these topics will be presented in detailed analyses in Paper I, II and III. Most interviews took place in the participants' 
homes, while some took place at the interviewees' workplace or in a public café, according to the interviewees' desire. Prior to interviewing participants for the study, I conducted a pilot interview with a friend, who is a lesbian parent. The interview guide was revised somewhat after this interview, and revised again after the first handful of interviews, as I learned what questions worked better than others (see Braun \& Clarke, 2013). For instance, I soon learned that a concrete opening question (like: "Tell me, when did you two first meet?") created a comfortable start for the interviewees, while open and abstract questions elicited more reflective responses when asked later on.

The interviews lasted between 41 and 101 minutes. All interviews were audio-recorded, and the total recording time was 63 hours and 37 minutes.

\section{Participants and interviews in Paper IV}

The interviewees in Paper IV were 29 women in 19 families. Ten of these women (from six families) were participants in the main study and are also included as interviewees in Paper I, II and III. The remaining 19 women in ten families were recruited specifically for Paper IV. All in all, the participants in Paper IV were between 26 and 45 years of age, and their children conceived through public healthcare were all under five years of age at the time of the interviews. About two thirds of the participants had university exams and one third had upper secondary exams. There was a geographical spread over Sweden among the participants and most of them were born in Sweden. Most participants were employed, but a few were unemployed, studying or on parental leave at the time of the interview.

Interviews took place in the participants' homes in most cases, and in cafés and libraries in a few cases. The interviews were audiorecorded and lasted between 54 and 108 minutes, with a total recording time of 22 hours and 34 minutes. 
The interviews conducted specifically for Paper IV followed a semistructured interview guide that specifically focused on their encounters with public fertility clinics. The interview guide followed the chronology of the treatment process, allowing participants to reflect on the different stages in their path to parenthood.

\section{Participants and interviews in Paper $V$}

Participants in Paper V were twelve children in eleven lesbian families. In most interviews the child spoke alone with one of the researchers. However, in a few interviews, parent(s) were present and sometimes participated. The children were born between 2002 and 2005, and were at the time of the interview between five and eight years of age. Five of the interviewees were girls and seven were boys. All children lived together with both mothers, and nine of them had siblings in their households. All children lived in southern or central parts of Sweden, ten in urban areas and two in rural districts. Eleven of the interviewees had been conceived through assisted reproduction with unknown sperm donors, while one child had been conceived through home insemination with a known donor.

A semi-structured interview guide was developed for the child interviews. During the interviews, the children were handed a large piece of paper and felt-tip pens, and were asked to draw a family. Most children responded by drawing their own family, given that the interview focused on the children's views of their own family. Thereafter, the interviewees were handed another piece of paper and asked to draw another family, and the interview focused on them. If the child initially had drawn an external family, the child was asked to draw their own family in the second picture. Departing from the children's own pictures, the interviewers asked questions like "What is a family?" and "What is a mummy?". The children were also encouraged to describe, in their own words, how they had been conceived.

The child interviews were video-recorded and the record time lasted between 21 and 72 minutes. Parents of the interviewed children 
participated in shorter structured interviews conducted after the child interviews. Those interviews aimed to capture an adult version of the family structure and how the child had been conceived.

\section{Transcription and data analysis}

The interviews have been analysed drawing on discursive psychology (Paper I and III) and thematic analysis (Paper II, IV and V). The methodology is more extensively presented in Chapter III. In the present section, I will describe how the interview data were dealt with in a concrete sense.

\section{Transcription and analysis in Paper I, II and III}

All interviews were transcribed verbatim, including both interviewees' and interviewer's talk. I did much of the transcription work myself, but also held some help from students. Some nonverbal expressions, such as laughter and sighs, have been noted in the transcriptions. Overlapping speech, intonation, pauses etcetera have not been noted. All names of persons and locations were replaced with pseudonyms.

Totally, the transcribed interviews for Paper I, II and III exceed 500,000 words. Prior to any attempt to analyse the material, I read through all of the transcripts several times. Thereafter, the well over thousand pages of transcribed text had to be organized and overviewed, so that I would not go astray in the data. My first step was to make a register over the interview content. Each interview was given a front page where the content of every transcription page was briefly summarized. These front pages were later helpful when I needed to quickly find a particular interview sequence.

My next step was to sort the interview data by topic. I read through all of the transcriptions once again, this time marking the text with different colours for different broad topics, e.g., "second-parent adoption", "encounters with healthcare". Text parts from all 
interviewees marked as covering the same topic were copied and put together in separate documents where they could be read together and compared. I departed from those documents for further analysis.

When working with Paper I and III, I searched for similarities and variations in the interview talk, aiming to identify specific rhetorical patterns in the data. In other words, I searched for interpretative repertoires (Potter \& Wetherell 1987, Wetherell \& Potter 1992). I also searched for subject positions located in the repertoires, and paid close attention to the rhetorical strategies drawn on by the interviewees. The creative, lively and challenging process of analysing discourse is not easy to describe in words. Wetherell and Potter claim that "Much of the work of discourse analysis is a craft skill, something like bicycle riding or chicken sexing that is not easy to render or describe in an explicit or codified manner" (Wetherell $\&$ Potter, 1992, p. 101). I could not agree more. The procedure has not followed a simple stage guide. Rather, the analytical process has been cyclical, moving me back and forth between transcripts and abstract notions. Much of the analytical work has of course taken place in front of my computer screen. However, the abstract analysing process of finding and interpreting patterns also continued in my mind at the grocery store, in the bathtub and not least while I was asleep. The analysis has also been an interactive process. Analyses have grown from supervision, seminary presentations, lecturing and discussions between co-writers. Previous versions of each paper have also been extensively revised according to suggestions form anonymous peer reviewers and journal editors.

In Paper II, interview sequences regarding second-parent adoptions were selected for a thematic analysis. I conducted an initial coding of the selected data and thereafter sorted the codes into candidate themes (Braun \& Clarke, 2013). These themes were further sorted into different sections that concern different aspects of the issue. A thematic analysis is also not a simple step-by-step process. Rather, the analysis moves back and forth between structuring the themes, selecting excerpts, writing the analysis, revising the themes and the structure, moving or replacing excerpts and rewriting text. Accordingly, Braun and Clarke (2006, p. 86-87) claim: "analysis is not a linear process of simply moving from one phase to the next. 
Instead, it is more recursive process, where movement is back and forth as needed, throughout the phases. It is also a process that develops over time." Throughout the work with this paper, themes were revised, some themes were combined and others were split up and renamed until the final structure was formed.

\section{Transcription and analysis in Paper IV and V}

The ten interviews conducted specifically for Paper IV were transcribed by Rozental, who also conducted the initial analysis on the data, under supervision of Zetterqvist Nelson and myself. A comprehensive presentation of these results can be found in Rozental's Master's thesis (2011). One part of the Master's thesis, regarding encounters with fertility clinics, underwent further analysis for Paper IV. Rozental and I conducted the analysis in collaboration. The six interviews from the main study that matched the focus of Paper IV were added to the analysis at this stage, and excerpts were selected from both datasets. We conducted a thematic analysis in line with the description above.

The child interviews for Paper V were transcribed by Möllerstrand and Wikström. They conducted the basic analysis on the data, under supervision of Zetterqvist Nelson and myself. The results are comprehensively presented in their Master's thesis (Möllerstrand \& Wikström, 2011). For the work with Paper V, I continued the analysis on the child interviews, focusing specifically on the children's talk about fathers and donors. I conducted a thematic analysis as outlined above.

\section{Ethical and methodological considerations}

The project follows the Swedish Research Council's rules and guidelines on ethics in research (Vetenskapsrådet, 2002). Ethical considerations have been included as an important part of the entire process. The interviews with parents and children raised different ethical and methodological questions, which are discussed in this 
section. I thereafter describe how I denominate family forms and family members in the thesis, and finally provide a reflection on my own personal background.

\section{Considerations on parent interviews}

As outlined above, most participants were found through their second-parent adoption protocol, a process that was approved by the regional ethical board at the university (Reg. no. 2010/247-31). Several researchers have previously utilized personal data from publically accessible court decisions to invite study participants (Eriksson \& Näsman, 2008; Rejmer, 2003; Schiratzki, 2008). In the present work, adoption protocols from district courts throughout Sweden were collected, and the identified parents were sent a letter inviting them to participate in the study. Once each letter had been sent, I crossed out all personal data, such as names and personal identification numbers, from the protocols. Once rendered anonymous, the protocols were stored for further analysis (Bergqvist, forthcoming) and for collecting descriptive data on the entire group. This way of contacting interviewees enabled a much more comprehensive invitation than what would have been possible through advertising or recruitment via LGBTQ associations. The interviewees were spread over the entire country, and several interviewees said that they had no contact with any LGBTQ community. I considered the risk that some parents would find this recruitment procedure intrusive. In order to minimize this risk, I explained in the invitation letter how their names had been found and that no personal data would be stored by the researchers.

All participation in the present studies has been voluntarily (Brinkmann \& Kvale, 2008; Howitt, 2010; Vetenskapsrådet, 2002; Willig, 2008). Invitation letters included information about the study, a description of broad aims and the planned interview procedure, assurance that any participation was voluntarily and that they could withdraw from the study at any time. The participants were also given contact information to the researchers and were invited to ask any questions. Along with the invitation letter, they 
received a consent form where they could leave their telephone number and e-mail address for further contact. All parents who returned the consent form were contacted via e-mail, thanked for their interest and informed that I planned to contact them over the telephone. I decided to schedule the interviews over the telephone, rather than e-mail, in order to give the interviewees an additional chance to pose any questions they might have about the project and receive the answers before agreeing to being interviewed. In one case, however, the interview was scheduled via e-mail, because the interviewee had explicitly written on her consent form that she preferred to be contacted this way.

All interviews took place at a time and location that suited the interviewees (Howitt, 2010). Most interviews were conducted during weekends and in most cases in the participants' homes. Children were at home during most of the interviews. Small children were usually present during the interview, if not asleep, while older children usually engaged in other activities in other rooms. One benefit of conducting interviews in the participants' homes, with children present, was that talking about family life comes quite natural in the family's own home. Unfortunately, the presence of young children meant that the interviews were constantly interrupted, because the children required attention (see Howitt, 2010). Furthermore, the noise made by children complicated the transcription a great deal, and some parts are inaudible. The presence of children has therefore impaired the flow of the interviews, as well as the quality of recordings in some parts. Parents in some families did not want their children to be present and had arranged for babysitting or invited me to come at a time when the children were asleep. Also, a few interviews took place in other locations, such as public cafés or at the participants' workplace. Again, the interviewees chose the settings and location.

Before starting each interview, I repeated some information about the research project, and described the planned continuation of transcribing and completing articles. The interviewees were asked for their consent on being audio recorded, and had a chance to ask questions before the recording was started. 
Most couples were interviewed together. Joint couple interviews differ in many respects from individual interviews (Bjørnholt \& Farstad, 2014). Joint interviews enable the couple to create their narrative together and build on each other's reflections. Also, a joint interview involves fewer ethical dilemmas concerning confidentiality, because both partners are present and the researcher does not have to keep one partner's claims secret from the other partner. A weakness of the joint interview is that topics like conflicts, distrust or dissatisfaction in the relationship may be harder to verbalize and may be toned down.

After the interviews had been transcribed, a copy of the transcription was sent to the interviewees (see Elliott, Fischer \& Rennie, 1999). The interviewees were encouraged to read the transcript, and to get in touch with me if there was anything they wanted to modify, clarify or delete. A handful of participants utilized this opportunity. In some cases, short parts or single words were corrected or clarified. In a few cases the interviewees chose to delete a longer part of the interview text, which they upon reflection did not feel comfortable about sharing. I had informed them in advance that they would be given this option. I chose this procedure to enable the interviewees to feel comfortable and like they could be open in the interview situation, knowing that they could later delete parts of the interview. Besides the immediate response after completed transcriptions, I have also updated the interviewees yearly via e-mail on what is being published in the project.

Paper I, II and III draw on a large interview dataset. A large dataset allows broader analyses, but involves a risk that the analyses will lack depth. One could argue that a smaller dataset suits discourse analysis better, because the researcher engages in detail with small text units (Holt, 2011). In the present thesis, I consider the comprehensive data to be a strength. The broad material has been useful when outlining the main findings, e.g. tracing central interpretative repertoires. Later, I selected short parts of the interviews for the detailed analysis. This means that several interviewees are not quoted in the papers, but all of them contributed to the findings. 


\section{Considerations on child interviews}

Interviewing children requires specific ethical and methodological considerations (Scott, 2008; James, Jenks \& Prout, 2006). The regional ethical board at the university approved the child study before the interviews were conducted (Reg. no. 2010/247-31).

When children are involved in research, formal informed consent is given by the parents (SFS 2003:460). In other words, the parents permit their children to participate. A child may, however, decline to participate, i.e. the child has the right to say no (Johansson \& Karlsson, 2013; Wyness, 2012). In a first step, an invitation letter with information about the study was sent to the parents. The letter contained information about the aim of the study and the planned procedure, and assured that any participation was voluntarily and that they had the right to withdraw at any time. The invitation also included a letter presenting the study to the children in simple language. If they approved of their children's participation, the parents were encouraged to read the information letter to their children and ask them about their interest in participation. In a follow-up phone call, some parents declined participation, either because they did not want their children to be interviewed, because the child did not want to be interviewed or because of lack of time. Most parents agreed to have their children interviewed and a time was set for the interview.

All child interviews were conducted during daytime, i.e. when the child was not expected to be tired. All children were interviewed in their homes, for two main reasons. First, the home was considered a safe arena for the children, where they could be comfortable during the interview (see Johansson, 2013; Wyness, 2012). Second, children's reflections are often highly contextual, thus talking about families and one's own family is facilitated by being in one's own home.

Before the interviews, the interviewers spent a good deal of time socializing with the children, in order to increase their comfort in the situation (see Hansen Orwehag, 2013). The children were involved in manipulating the video camera, so they could switch the camera 
off and on, and in that sense gain control over the interview situation. The preference was that the child should speak alone with the researcher, but if a child desired to have parent(s) present, this was respected.

During the interviews, the interviewers paid close attention to the children's own stories, following their paths (see Hansen Orwehag, 2013). The interviewers' goal was to hear the children's voices in their own right and to maintain the children's confidence in the interview situation. The children were asked questions based on what they drew in their pictures, like "What is a family?", "What is a mummy?" and "What are mummies for?" They were not asked any questions that drew attention to their own family form as a minority. Before the interviews, we decided that the interviewers would not ask the children anything about fathers, unless the children themselves talked about fathers. All but one of the interviewees brought up fathers during the interview, and were therefore asked what a father is, and in most cases also what a father is for.

\section{Denominating the families: Same-sex families, lesbians, LGBTQ, mothers, father and donors}

The family form in focus for this thesis could be described as families established by two women in an intimate relationship, who together parent one or more children conceived through assisted reproduction. Those families would most correctly, to my mind, be denominated families with female same-sex parents. Using such a phrase repeatedly, however, gets a bit tedious. For improved readability, I have chosen to use the terms lesbian families and samesex families interchangeably. Both these concepts correspond to how this group is generally labelled in the research literature written in English. They are not, however, accurate synonyms. Lesbian families are not always established in intimate couple relationships, and women in same-sex parenting dyads do not always self-identify as lesbians. Both denominations, lesbian and same-sex, are frequently used by the interviewees in the present study, when the adult participants talk about themselves and their family form. 
However, participants also spontaneously describe themselves using a variety of labels, such as homosexual, bisexual, gay, and dyke (in Swedish flata) and their relationship as two women or girl couple. The concept queer is also employed by some participants, when discussing their families in a political framework. When I talk about lesbian families or same-sex families in the thesis, this must not be understood as excluding participants who prefer other labels. An alternative to same-sex could have been same-gender. Generally, I employ the word gender rather than sex in the text, because gender acknowledges the social and psychological dimension of the matter (see Butler, 1996; West \& Zimmerman, 1987). In the research field of lesbian and gay studies, however, same-sex is a well-established concept, while same-gender is less frequently seen.

Another concept frequently used by the participants and myself during the interviews is rainbow families (in Swedish regnbågsfamiljer). While this term is well established in the Swedish LGBTQ community, it is not (yet) very frequently seen in the English language literature. I have therefore decided not to use that concept in my present English writings. More commonly seen in English is the acronym LGBTQ families, a term I employ when I refer to the large and disparate collection of lesbian, gay, bisexual, transgender and queer families. The acronym has developed over the past decades from the initial LGB acronym, where both a $\mathrm{T}$ and a $\mathrm{Q}$ are most often added at present. An $I$ for intersex, an $A$ for asexual and a $P$ for polyamorous could be appended to the acronym as well, and they sometimes are. In the present work, however, I conform to how the acronym is most often employed in the contemporary research literature.

In the present thesis, female parents are denominated parents and mothers interchangeably and regardless of birth status or biological ties to the child. Naming a lesbian birth mother mother has not been problematized in this research field. In contrast, how to denominate lesbian non-birth mothers has been the subject of debate (Brown \& Perlesz, 2007, 2008; Padavic \& Butterfield, 2011). Suggestions include names like non-biological mother, non-biological parent, non-birth mother, non-birth parent, co-mother, co-parent, stepmother, stepparent, social mother, social parent and other 
mother (Brown \& Perlesz, 2008). The very issue of her name sheds light over the negotiability that follows this un-normative way of having children. Proponents of the $c o$ - prefix argue that she should be named for what she is, rather than what she is not, i.e. objecting to names with the non-prefix. Others would argue that the $c o$ - prefix puts her in a secondary position, as a sort of 'tag-along-mum'. When I decided to simply call all my adult participants mothers, this was in accord with how most of the interviewees self-identify. The vast majority of the adult participants in the studies label both themselves and their partners as mothers, and a majority of the interviewed children talk about both their parents as their mummies. However, different positions in a family have sometimes been of central relevance to the analysis of the interview data. In those cases, I have chosen to separate the mothers by labelling them as non-birth mother and birth mother, respectively. I do agree with critics who stress that the term non-birth mother puts the focus on what this person is not or did not do. I also considered the label social mother. However, the term social mother does not accurately differentiate between the mothers, because both function socially as mothers. Furthermore, I argue that when differences between the parents are brought up, the issue usually concerns being a mother without having given birth. The concept non-birth mother, thereby, most accurately captures the issue at stake.

Men who contribute with their semen to the lesbian couples' pregnancies, without taking part in the nurturing of the child, are here denominated as donors. Men who share parental responsibly with their lesbian friends are denominated as fathers. This is in accord with how the vast majority of the adult participants talk about their families. Among the interviewed children, however, none uses the formal word donor. While some children talk about this person as a man or a guy, others say seed-daddy or daddy. Previous studies have shown that a sharp distinction between fathers and donors is not always applicable, neither for the donors/fathers (Dempsey, 2012) nor for the children (Goldberg \& Allen, 2013a; Vanfraussen et al., 2001). My denomination is therefore a simplification of a more complex issue, which suits the adult research discourse. 
In the present work, couples consisting of a woman and a man are most often denominated as different-sex couples. I prefer this labelling over heterosexual couples, because most often it is the fact that there is a woman and a man in a relationship or a parenting unit that is of interest, rather than how they would self-identify their sexual orientation. When I refer to heterosexual couples or heterosexual families I specifically mean self-identified heterosexuals, or relate to how the family form is denominated by others.

\section{Personal reflexivity}

My own personal background has several similarities with the participants in the present study. In accordance with the adult interviewees, I share the experiences of living in Sweden, being an adult and being a woman. Also, I share the experience of having children conceived in a lesbian relationship. Like most interviewees, I have employed a fertility clinic in Denmark in order to have children. I share the experiences of being both birth mother and nonbirth mother and have gone through two second-parent adoptions. Besides sharing several similar experiences with the participants, I also differ from the group in some important ways. Unlike most of the adult interviewees, I have gone through a divorce and no longer live in an intimate relationship with my oldest children's other mother. I self-identify as bisexual and polyamorous, and thus reflect on lesbian monogamous couple relationships from an outside perspective. Moreover, my youngest children were conceived outside monogamous relationships.

Feminist researchers have discussed the advantages of having personal experiences similar to the participants' (Letherby, 2003; Sprague, 2005). When researchers are 'insiders', they are already familiar with the topic at hand and may benefit from a nuanced understanding of the interviewees' situation (Berger, 2015). When researchers, on the other hand, have privileged positions in relation to the interviewees, there is risk of 'othering' or exotifying the participants (Kitzinger \& Wilkinson, 1996; Sprague, 2005). 
Privileged researchers may not even realize what aspects they are missing when trying to represent the other. Similarities between researcher and participant could therefore be beneficial. The 'insider' position may also facilitate access to participants (Berger, 2015). I acknowledged these advantages when working with the present research project. First of all, identifying participants through their second-parent adoption protocols turned out to be a very good way of getting in touch with a large number of families. If I had not had personal experiences of the adoption procedure, I would probably not have thought of this option when searching for interviewees. Furthermore, I explained already in the invitation letter that "There are experiences of same-sex family making within the research group." Some interviewees told me that this had been important for them when deciding to participate, because they felt more comfortable knowing that I had similar experiences myself. If the interviewees raised questions about me or my family during the interviews, I gave them honest and open answers. I do believe that, for several interviewees, my self-disclosure was important in promoting open and reflective talk. Also, based on my own experiences, I was able to ask follow-up questions that might not have occurred to someone with less experience of lesbian families. This has probably enabled deeper and more profound reflections.

On the other hand, having personal experience similar to the interviewees' could also be obstructive (Almack, 2008b; Berger, 2015; Hurd \& McIntyre, 1996). Some issues might be shared 'common sense' within the lesbian community, and therefore never verbalized in the interviews. If I, as an interviewer, had not had those experiences, the interviewees might have been asked to explain their thoughts and reflections in a more detailed and explicit manner. Also, having personal experiences of the research topic implies a risk that some things are incorrectly taken for granted, if the researcher does not realize that similar experiences could give rise to completely different thoughts, desires, hopes and doubts in different people. Roni Berger (2015, p. 224) highlights the risk of the researcher becoming self-involved "to the degree that it blocks hearing other voices". To avoid such pitfalls, I made an effort to ask open questions, trying not to guide or limit the interviewees. Still, I believe it is never possible to put one's own experiences in 
parentheses, neither as an interviewer nor as an analyst. Therefore, like any research, the findings must be understood in their specific context.

One ethical dilemma that arises when doing research on minority groups is that the participants have trusted me with their narratives and likely expect me to tell their story, but the work as a qualitative researcher, in particular as a discourse analyst, is not simply about retelling but also analysing what the participants have shared. Feminist researcher Gayle Letherby acknowledges such potential conflict, and claims: "We do 'take away their words' and then analyse the data from our own political, personal and intellectual perspective" (Letherby, 2003, p. 78). My ambition has been to analyse the interviews with care, but without losing a critical view. I do believe that my personal position of presently not living in a lesbian monogamous relationship has given me a more critical and scrutinizing perspective when looking closely at lesbian normativity.

I have less common ground with the interviewed children in the present study. I grew up in a nuclear family with my biological mother, father and siblings some decades before these interviewees, and had never even met anyone who openly identified as nonheterosexual before coming out myself as a teenager. Thus, I do not share with the interviewees experiences of growing up in a nonheteronormative family form. I do, however, have parental experience of children in lesbian families, children of the interviewees' ages. This experience was beneficial when discussing with my fellow researchers how to construe the interview guide and plan the interview procedure. I have also sometimes, when working with the child interviews, turned to my own children, as experts (see Wyness, 2012), to ask whether my interpretations sound reasonable to them.

One strength of the present research project is the collaborative work that has been done between the involved researchers (see Elliott et al., 1999). The work with all five papers has been performed in a dialogue with my supervisors, and students have worked with the data in Paper IV and V. Our different eyes, perspectives and reflections have strengthened the data collection and analysis a great 
deal. Together, my co-workers and I have also brought different perspectives in line with our different positions as female and male, homo-, bi- and heterosexual, parents and non-parents, young adults and middle-aged adults. 


\section{Chapter V}

\section{Summary of findings}

This chapter provides an overview of the findings in each paper.

\section{Findings in Paper I: On encounters with maternal and child healthcare}

Paper I draws on a core finding from the interviews I conducted with 96 parents in 51 families. When leaving the families after the interviews, I was most often filled with a warm and positive feeling. Not only had I encountered loving, proud parents who shared with me their wise thoughts and reflections, I was also left with the impression that being a lesbian family in Sweden today is primarily joyful journey during which overt discrimination seldom takes place. When listening to the interviews during the transcription process, I heard descriptions of positive encounters over and over again, e.g. "we have been lucky", "everyone is positive", "we have never encountered difficulties". I realized that I was tracing a core interpretative repertoire.

My initial analysis for Paper I was broad and inclusive. I collected all interview parts in which the interviewees discussed their encounters and relationships with people outside their immediate family. To meet the standards of a research article, I later decided to narrow my analytical focus to only regard encounters with healthcare providers. Because most parents spoke about healthcare encounters during pregnancy, childbirth and in regular child healthcare check-ups, I limited the focus to these settings. When the 
data were scrutinized in detail, two main interpretative repertoires were found. First, the most dominant repertoire was the "just great repertoire," where healthcare providers were depicted in positive terms, as warm and caring or even wonderful and amazing. Also, within the 'just great' repertoire, it was recurrently claimed by the interviewees that they had not encountered any problems or negative experiences. The second repertoire was labelled "heteronormative issues". When drawing on this repertoire, the interviewees overtly expressed dissatisfaction with deficient treatment in healthcare contacts, which they related to them being a lesbian couple. Interestingly, most parents drew on both those interpretative repertoires in their interviews, and oscillated between them. I saw that the 'just great' repertoire often mitigated the 'heteronormative issues' repertoire. Either, heteronormative prejudice was presented as an exception from a more positive 'otherwise', or the deficient treatment was justified by the interviewees' claims that the healthcare providers had had good intentions. The findings could be understood in relation to a discourse of 'good parenthood', in a society where parents generally are held morally accountable for their children's health and happiness. At the time the interviews were conducted, same-sex parenting had only been legally recognized for less than a decade. Lesbian families were (are) still questioned, and a central argument against same-sex parenting was that the children would suffer from homophobic prejudice. The 'just great' repertoire could be understood in relation to this context, where the unproblematic journey serves to present the interviewees as 'good parents', who are not exposed to any prejudice.

\section{Findings in Paper II: On second-parent adoptions}

Paper II builds on the same interviews as Paper I, but focuses on second-parent adoptions. Second-parent adoptions have only been permitted for lesbian couples in Sweden since 2003, and gave samesex couples the first possibility to share legal parenthood. Previous Swedish research has discussed the disadvantages of not being able to share legal parenthood. Based on that, I decided to include 
questions about the second-parent adoption process in the interviews, and analyse the responses in an article. The importance of having both mothers recognized as legal parents has also been stressed in several international research articles. Despite this, the process of going through second-parent adoptions has only been studied to a limited degree. Paper II therefore fills an important gap in the research field.

The findings were divided into three sections: "meaning and impact of the adoption," "going through the adoption process" and "encounters with social workers." I show in Paper II that the adoptions were considered crucial to most interviewees, who described experiencing stress about having the adoption granted as soon as possible and great relief once it had been granted. Not being a legal parent was depicted as impacting negatively on everyday life, where non-birth mothers were not allowed to make legal or medical decisions for their children. The core impact of the adoption was also visualized through the parents' descriptions of how family planning itself was dependent on the legal situation, e.g. some interviewees described how they had postponed having children until the secondparent adoption law was granted. Despite the predominating picture of the adoption as crucial, I also found some interviewees who claimed that, in an emotional sense, the adoption was completely inessential, being 'just a piece of paper'.

Going through the adoption process as such was for the most part depicted as a comprehensive procedure, which many interviewees sharply criticized. The process includes several steps and often lasts for several months before the child is finally granted the legal bond to the non-birth mother. Also, some interviewees depicted the procedure as stressful and strenuous to go through. Others, however, depicted the process as having been quite simple for them.

Interviewees' descriptions of their encounters with social workers, who assess the non-birth mother before the adoption, were also analysed in the paper. In many interviews, the social workers were depicted as unprofessional, asking irrelevant or intrusive questions. Also, several participants criticized the social workers' focus on male role models, and the heteronormative family ideals underlying 
such a focus. Despite being critical of the social workers, interviewees claimed that they had not been comfortable with directing their critique towards the social workers themselves, ultimately because the adoption decision depended on the social workers' assessments. In the data, I also found interviewees depicting the social workers as nice, competent and professional. Hence, the description of the encounters differed a great deal between the interviews.

Based on the findings, I argue that the lengthy and comprehensive process of a second-parent adoption is not the optimal way of granting legal parenthood to non-birth mothers. For lesbian couples who conceive after fertility treatment in public healthcare, the nonbirth mother is recognized as a legal parent after her written consent, i.e. without the adoption process. I argue that such a procedure would be beneficial for lesbian families who conceive elsewhere as well.

\section{Findings in Paper III: On equality in parental relationships}

A discourse analysis of the 96 interviewees' talk on equality in their parental roles is presented in Paper III. Lesbian women have been showed to strongly emphasize relationship equality, and Sweden is known to be in the forefront of gender equality politics and norms. Therefore, Swedish lesbian mothers could be expected to highly embrace ideals of equality. How lesbian mothers in Sweden talk about equality, however, has not been analysed before.

When scrutinizing the interviewees' talk on equality in their joint parenthood, I found three different interpretative repertoires, each drawn on in about one third of the interviews. In the first repertoire, "the unison repertoire," the interviewees presented themselves as fully equal. They depicted their equality as having been spontaneously achieved, and most often did not make any references to status as birth mother and non-birth mother. In a second repertoire, "the struggling repertoire," equality was depicted as the potential outcome of hard work and struggle. Unlike the unison repertoire, 
here status as birth mother and non-birth mother was claimed to be crucial, in that the birth mother gains an automatic position as the primary parent. This difference between the parents was presented, from the perspective of this repertoire, as an enemy that must be fought until the mothers eventually reach their equal positions. In the final repertoire, "the biologistic repertoire," the birth mother was also presented as the primary parent. Within this repertoire the difference between the parents was not problematized, rather presented as natural and self-evident following the given frames of biology.

The different repertoires are discussed in relation to the concepts 'homonormativity' and 'heteronormativity'. The unison repertoire shows a homonormativity in which equality is depicted as spontaneously earned and where birth giving is claimed to be irrelevant. This forms a homonormative way of presenting one's relations as independent of the surrounding heteronormativity. Both of the other repertoires adhere to heteronormative discourses, because lesbian parenthood is discussed in gendered terms in which biology sets the core limitations. Within the struggling repertoire, equality is depicted as an ideal that requires a struggle, similar to that of parents in egalitarian different-sex relationships, whereas the biologistic repertoire presents a homonormativity that leans on traditional heteronormativity.

\section{Findings in Paper IV: On encounters with public fertility clinics}

Paper IV presents descriptions of encounters with fertility clinics in Swedish public healthcare, based on interviews with 29 women in 16 families. Swedish public healthcare has a long tradition of meeting and treating involuntarily childless different-sex couples, but has only been available for lesbian couples since 2005. In the paper, it is shown how heteronormative assumptions about the family, and a feeling of exposure in the patient role, led the women to talk about themselves as vulnerable. Routines at the clinics were not adapted to the lesbian women's specific needs, and neither were 
the offered treatment programmes as such. Rather, routines and offered treatments were adjusted to the specific needs of differentsex couples with medically caused infertility and years of previous trials in getting pregnant on their own. The interviewees depicted themselves as information centres, because they were required to explain specific regulations for lesbian parents to the healthcare providers. They also depicted the treatment process as bureaucratic, and as lacking in support and care.

When describing how deficient treatment was dealt with, the interviewees' claims were filled with expressions of acceptance, which rhetorically minimized the impact of deficient treatment. Parents expressed their gratefulness for having access to fertility clinics at all, and claimed to understand the staff's lack of knowledge about lesbian families. Others expressed a laissez-fair attitude to deficient treatment, or drew on humour and irony to distance themselves from it. In an attempt to avoid deficient treatment, some interviewees described a strategy of being one step ahead, and actively choosing healthcare providers known to be competent in treating lesbian couples. All in all, the study concludes that access to fertility clinics is of core relevance to lesbian couples, but that heteronormative bias in clinic routines and offered treatments must be dealt with as the next step.

\section{Findings in Paper V: On children's talk about fathers and donors}

The children themselves are in focus in the final paper. Based on interviews with twelve children in eleven families, Paper V portrays children's talk about fathers and donors. The interviewees were between five and eight years of age, and all lived in families with two mothers and no father. In the interviews, the children described families as being constituted by emotional and physical closeness it is the fact that we care for each other and live together that makes us a family. Mothers were depicted as good at taking care of children. Both these findings accord well with how, in the previous research, children have talked about families and mothers. When 
talking about fathers, children in lesbian families differ from other children who have talked about fathers in other studies. Therefore, the interview parts regarding fathers were selected for a more detailed analysis. First of all, several children claimed that it was harder to describe what a daddy is than what a mummy is, and some referred to the fact that they do not have a father as a reason why they could not answer. Eventually, most children did talk about what a daddy is, and most often a daddy was described as 'the same' as a mummy, doing the same things, i.e. taking care of children. Children in previous studies have generally depicted fathers as someone to play or do sports with, i.e. as being different from the caregiving mothers. The children in the present paper, however, mainly depicted mothers and fathers in terms of similarities.

When talking about their own conception, all interviewees referred to having been inside the belly of one of the mothers. Some children talked about an egg and some about a seed, and some of them talked about both the egg and the seed. A few children referred to the seed without mentioning the person producing it. Others referred to the person as a man or a guy. Yet others referred to him as their 'daddy' or 'seed-daddy'. In these stories, the children oscillated between claiming that they do not have a father, in a relational sense, and that they do have a father in a genetic sense. Sometimes these descriptions are confusing to the listener, and they may also be confusing for the children. Thus, calling a sperm donor father or daddy gives rise to confusion. 


\section{Chapter VI}

\section{Discussion}

The broad aim of the present thesis is to provide knowledge about Swedish lesbian parenting couples and their children in a time of legal recognition, the time period since lesbian couples gained access to shared legal parenthood in 2003. In this chapter, I will first discuss contemporary Swedish lesbians' path to parenthood situated in its historical and geographical context, with a focus on the options following the legal changes. The thesis also sets out to focus on the interplay between family members within lesbian families, and between the family members and their surroundings, and to visualize and analyse notions of heteronormativity and homonormativity in contemporary Sweden. Later in this chapter, I will return to these specific aims and discuss how the present thesis contributes to them.

The year 2003 can be described as seeing a paradigm shift in the Swedish legislation on same-sex parenting. Before 2003, a child could only have two legal parents if one of them was a woman and one of them was a man (Proposition 2001/02:123). Legal parenthood was not necessarily bound to biological parenthood (i.e. a nonbiological parent could be recognized as a legal parent, for example through adoption, SFS 1949:381), but legal parenthood was bound to gender. Accordingly, for same-sex couples raising children prior 2003 , only one of them could be the child's legal parent. The legal change in 2003 redrew the options fundamentally for lesbian and gay families: two parents, regardless of gender, could now share legal parenthood of their children. Same-sex couples were thereby recognized as fully sufficient parents.

In previous studies on lesbian families in Sweden, participants generally described a preference for having children in co-parenting 
arrangements with gay men (Ryan-Flood, 2009; Zetterqvist Nelson, 2007). Fathers were depicted as crucial to children: It was considered important to have a relationship with one's father and to have knowledge about one's genetic origins. Turning to fertility clinics for donor insemination was depicted as a secondary choice, if finding a man to co-parent with had failed. The present interviews give a completely different picture, where donor insemination generally has been chosen in favour of other options. Interviewees reflect over shared parenting outside their intimate relationship as being complicated, involving to many wills, and comparable to the situation of a divorce, where children also oscillate between two households. Before the legal change in 2003, a co-parenting arrangement with a man was the only way for a lesbian couple to ensure the child two legal parents. After the legal change, two mothers could be legal parents on their own. The restriction of allowing two legal parents - but not three or four - means in practice that involving a man, who keeps his legal status as father, would hinder non-birth mothers from second-parent adoption. Rather than emphasizing the importance of an active father, the contemporary families often highlight the importance of non-birth mother's legal parenthood and their desire to have a second-parent adoption. It is possible that the legal situation impacts on the chosen paths to parenthood.

When comparing the situation for lesbian families in Sweden to that of lesbian families in other Western countries, it is clear that the legal situation is central to how families are formed, and what obstacles parents deal with. In nations and states where joint legal parenthood is not an opinion, research indicates the insecurity children face if their parents divorce, or if one parent dies (Gartrell et al., 2006, 2011; Hunt Federle, 2005; Killian, 2010). In the present thesis, such insecurity is generally limited to the time lapse between the birth of a child and until the second-parent adoption is completed. Swedish lesbian couples' access to fertility treatment in public healthcare, since 2005, also provides unique options. Most regions offer taxfunded insemination and IVF at a low individual cost to the patients. Therefore, for many lesbian couples in Sweden, access to medically assisted reproduction is not a matter of financial ability. Unlike findings from North American research, where medically assisted 
reproduction is often expensive, and procreation method is described as dependent on social class (Mezey, 2008), the interviewees in the present study seldom described their financial situation as an obstacle. Swedish law also allows same-sex couples to jointly apply for adoption. This legal change, however, has not been followed by practical opportunities for same-sex couples, thus lesbian couples generally have children through birth giving. Joint adoption is a well-established path to parenthood for lesbians in countries like the United Kingdom, the United States and Canada (Ausbrooks \& Russel, 2011; Averett, Nalavany \& Ryan, 2009; Brown et al., 2009; Farr \& Patterson, 2009; Goldberg et al., 2007; Hicks, 2011; Kinkler \& Goldberg, 2011; Ross et al., 2008; Woodford et al., 2010), again in contrast to results from the present Swedish study.

Lesbian parents' relations to their surroundings have been specifically focused on in Paper I, II and IV, where encounters with reproductive healthcare and social authorities are scrutinized. The topic of lesbians' encounters with reproductive healthcare has largely been researched internationally (Cherguit, Burns, Pettle, \& Tasker, 2013; Dahl, Fylkesnes, Sørlie \& Malterud, 2013; Dahl Spidsberg, 2007; Hayman et al, 2013; McManus, Hunter \& Renn, 2006; Peel, 2010; Shields et al., 2012; Wilton \& Kaufmann, 2001), and somewhat researched in Sweden (Larsson \& Dykes, 2009; Röndahl et al., 2009). Previous studies in the field generally describe patients' experiences as such, often pointing both at positive aspects of encounters, such as meeting with competent and well-informed staff, and at discrimination and prejudices. The unique contribution of Paper I lies mainly in the focus on how the participants talk about their encounters. It is shown how negative experiences are brought up by the interviewees, on the one hand, but are rhetorically mitigated as just being exceptions from a positive 'otherwise,' or justified because the staff is claimed to have meant well, on the other. Similar findings have been shown in relation to how lesbian parents talk about bullying of their children: Such experiences are also mitigated by the parents (Clarke, Kitzinger \& Potter, 2004). Bullying of children is an important issue for parents to address, and they do. At the same time, they risk undermining other interests, because opponents of LGBTQ families generally argue that same-sex adoption or assisted reproduction should not be permitted, because 
the children will be bullied (Clarke, 2000, 2001; Clarke et al., 2004; Malmquist \& Zetterqvist Nelson, 2008; Speer \& Potter, 2000). The parents are therefore caught in an ideological dilemma (Billig, 1988). The present work highlights a similar ideological dilemma. When lesbians talk about healthcare contacts, they are balancing between addressing prejudice, and mitigating the same. This is done using rhetoric that avoids feeding opponents of lesbian families with one of their core arguments, i.e., that society is not ready for lesbian families. This is heteronormativity at play: Parents who deviate from the normative expectations on family structure risk being positioned as 'others' if deficient treatment is extensively criticized.

Paper IV makes an additional contribution to the understandings of heteronormativity. Paper IV shares with Paper I a focus on healthcare settings, but specifically regards encounters with public fertility clinics. In this context, the legal situation is of importance to the findings. In some of the interviewees' stories, deficient treatment is mitigated with reference to the novelty of including lesbians in public fertility treatment. That lesbian couples have access to such treatment at all is depicted with a gratitude that shadows any critique of deficiencies in the treatment. Paper IV shows that the treatment offered in the public regime is adapted to the different-sex couple's situations, where medically caused fertility problems bring the couple to assisted reproduction. For lesbian couples, however, assisted reproduction is often sought without any medically caused infertility. Therefore, other kinds of treatment than what is offered might be more suitable for those couples. E.g., a lesbian woman with no known health problems will benefit from more insemination trials before turning to IVF treatment, whereas the Swedish clinics generally offer only one or a few inseminations before IVF is suggested. Such a treatment arrangement is well suited to women in different-sex relations, with years of previous failed pregnancy trials behind them.

While Paper I and IV deal with healthcare settings, Paper II focuses on encounters with social authorities, in the context of second-parent adoption processes. The tendency of rhetorically mitigating heteronormativity is not seen in the interviewees' talk about those encounters. Rather, the interviewees raise sharp critique when 
depicting uninformed social workers, whom they portray as intrusive, prejudicial and incompetent. The difference is interesting: Why are healthcare staff's deficiencies justified, while social workers' deficiencies are frankly criticized? Is deficient treatment in healthcare contexts milder? Or less overt? Are healthcare staff less prejudicial? Because the present work builds on interviews on encounters with professionals, rather than recordings from actual encounters, this is not easily assessed. The contexts as such differ, however. The interviewees have sought healthcare because they desire the treatment, and most prospective parents, regardless of relationship form, do encounter healthcare during pregnancy and childbirth. Thus, encountering healthcare is in many ways the ordinary way of 'doing parenthood.' The adoption procedure offers quite a different context: Most interviewees depicted their frustration about having to go through the adoption process, and the process as something they would have preferred to avoid if only legal parenthood could have been obtained in another way. Encountering social authorities is also unfamiliar to most well-functioning parents. In the healthcare context, the parent could expect to be cared for, while in the context of a second-parent adoption process, the parent is being assessed. These contextual differences may cause the different kinds of rhetoric used in the interviews.

Paper III engages with the relations between family members, as it focuses on how the participants construe equality and inequality in their parental roles. Sweden is often described as more gender equal than other Western societies (Ahrne, Roman \& Franzén, 2003; Magnusson, 2008; Ryan-Flood, 2009), with dual earners being the most common family form, and extensive access to parental leave offered to both mothers and fathers (Sverige Statistiska Centralbyrån, 2012; Swedish Social Insurance Agency, 2012). Lesbians are typically described as forming more equal relationships than different-sex couples (Bos \& van Balen, 2010; Bos et al., 2007; Chan et al., 1998; Ciano-Boyce \& Shelley-Sireci, 2002; Goldberg et al., 2012a; Patterson, Sutfin, \& Fulcher, 2004; Perlesz et al., 2010; Tasker \& Golombok, 1998), thus Swedish lesbians could be expected to put great emphasis on equality. The present study shows that most participants depict equality as an ideal, where some claim that their equality was spontaneously achieved. Others, however, 
depict equal parental roles as an ideal to strive for, but not as easy to actually achieve. Interestingly, about one third of the interviewees also depict different parental roles as 'naturally' following the different positions as birth mother and non-birth mother, where birth mothers are described as naturally being alert to the children's signals. The study shows how homonormativity is presented varyingly, where some interviewees depict the lesbian relationship as spontaneously equal, while others depict inequality.

Paper V is the only part of the present thesis that turns to the children themselves, with its focus on how children talk about fathers and donors. While the children in most respects talk about families in ways similar to how children in other family forms talk, their talk about fathers differs from that found in previous studies on children in heterosexual families (Bäckström, 2006; Morrow, 1998; Newman, Roberts \& Syré, 1993; Oliveira-Formosinho, 2009; Rigg \& Pryor, 2007). Children in heterosexual families often talk about mothers and fathers in terms of differences, where mothers are depicted as caregivers, and fathers as fun to play with or do sport activities with. The children in the present study also present mothers as caregivers, but when asked about fathers they claim that fathers are 'the same' as mothers, as taking care of children. It may be that the children's picture of fathers reflects the equality ideal, seen in the parental interviews in Paper III. With two caregiving mothers, the children might consider caregiving to be the core feature of any parent.

To sum up, the present thesis contributes to a broadened understanding of family practices. The thesis focuses on lesbian families in contemporary Sweden, a group of families that has only received limited attention in previous research. The focus on lesbian families broadens the field of family studies in Sweden, and the Swedish focus broadens the field of lesbian family studies internationally. The specific focus on lesbian couples with young children enables more profound knowledge about this particular group of families, whose stories, options and challenges are scrutinized in detail. At the same time, the limited focus does not accord with the diversity and multiplicity of family forms within the LGBTQ community. The present thesis does not contribute to the 
understandings of (voluntarily or involuntarily) childless lesbians, single lesbian mothers, lesbians in co-parenting arrangements with men, polyamours or transgender lesbian families, lesbian parents with adolescent or adult children, lesbian step-families or any other kind of lesbian or non-lesbian family form. The chosen focus enables a deeper engagement with one specific family form, at the price of a wider mapping of diversity. In the broad field of LGBTQ family studies, there is still a plethora of Swedish family forms, issues, ideas and norms left to research in the future.

I finish with a comment on the title, Pride and Prejudice: Lesbian Families in Contemporary Sweden. The title is of course chosen with reference to Jane Austin's famous novel (1971 [1813]), written in a time when the very existence of female novelists challenged societal norms. The present thesis is compiled in a far different context, yet also highlighting women who challenge normativity. Pride and prejudice are central in these women's talk about their families. The pride over their families is visible in all empirical papers. The papers that reflect talk about encounters with others recurrently depict deficiencies, which are often presented by the interviewees as prejudices. Thus, notions of pride and prejudice are intertwined in contemporary Swedish lesbian family stories. 


\section{References}

Abelsohn, K., Epstein, R., \& Ross, L. (2013). Celebrating the "other" parent: Mental health and wellness of expecting lesbian, bisexual, and queer non-birth parents. Journal of Gay \& Lesbian Mental Health, 17(4), 387-405.

Ahmed, S. (2006). Orientations: Toward a queer phenomenology.

GLQ: A Journal of Lesbian and Gay Studies, 12(4), 543-574.

Ahrne, G., Roman, C., \& Franzén, M. (2003). Det sociala landskapet. Gothenburg: Förlaget Korpen.

Almack, K. (2008a). Display work: Lesbian parent couples and their families of origin negotiating new kin relationships. Sociology, 42(6), 1183-1199.

Almack, K. (2008b). Women parenting together: A reflexive account of the ways in which the researcher's identity and experiences may impact on the processes of doing research. Sociological Research Online, 13(1-2).

Alving, B., \& Alving Olin, R. (2009). Bang om Bang. Möklinta: Gidlund förlag.

Anderssen, N., Amlie, C., \& Ytterøy, E. A. (2002). Outcomes for children with lesbian or gay parents. A review of studies from 1978 to 2000. Scandinavian Journal of Psychology, 43(2), 335351.

Archakis, A., \& Lampropoulou, S. (2009). Talking different heterosexualities: The permissive, the normative and the moralistic perspective -- evidence from Greek youth storytelling. Discourse \& Society, 20(3), 307-326.

Arita, K. (2006). Lesbian mothers in Japan: An insider's report. Journal of Lesbian Studies, 10(3-4), 105-111.

Ausbrooks, A., \& Russell, A. (2011). Gay and lesbian family building: A strengths perspective of transracial adoption. Journal of GLBT Family Studies, 7(3), 201-216.

Austin, J. (1971). Pride and prejudice. Westerham: Watts. 
Averett, P., \& Hegde, A. (2012). School social work and early childhood student's attitudes toward gay and lesbian families. Teaching in Higher Education, 17(5), 537-549.

Averett, P., Nalavany, B., \& Ryan, S. (2009). An evaluation of gay/lesbian and heterosexual adoption. Adoption Quarterly, 12(3-4), 129-151.

Bax, M. (2012, 29 March). De första samkönade att få adoptera. $Q X$. Retrieved from http://www.qx.se/Xtra/liv/20532/de-forstasamkonade-att-fa-adoptera

Beck, U., \& Beck-Gernsheim, E. (1995). The normal chaos of love. London: Polity Press.

Becker, A., \& Todd, M. (2013). A new American family? Public opinion toward family status and perceptions of the challenges faced by children of same-sex parents. Journal of GLBT Family Studies, 9(5), 425-448.

Beeson, D., Jennings, P., \& Kramer, W. (2011). Offspring searching for their sperm donors: How family type shapes the process. Human Reproduction, 26(9), 2415-2424.

Ben-Ari, A., \& Livni, T. (2006). Motherhood is not a given thing:

Experiences and constructed meanings of biological and nonbiological lesbian mothers. Sex Roles, 54(7-8), 521-531.

Berger, R. (2015). Now I see it, now I don't: Researcher's position and reflexivity in qualitative research. Qualitative Research, 15(2), 219-234.

Bergqvist, M. (forthcoming). As if they were a family: The construction of family and parenthood in female same-sex couples' second-parent adoptions. (Bachelor's thesis, Linköping University, Department of Social and Welfare Studies).

Berkowitz, D., \& Ryan, M. (2011). Bathrooms, baseball, and bra shopping: Lesbian and gay parents talk about engendering their children. Sociological Perspectives, 54(3), 329-350.

Betänkande från lagutskottet 1993/94:LU28. Registrerat partnerskap m.m.

Biblarz, T., \& Stacey, J. (2010). How does the gender of parents matter? Journal of Marriage and Family, 72(1), 3-22.

Billig, M. (ed.) (1988). Ideological dilemmas: A social psychology of everyday thinking. London: Sage. 
Bjørnholt, M., \& Farstad, G. (2014). 'Am I rambling?' on the advantages of interviewing couples together. Qualitative Research, 14(1), 3-19.

Borneskog, C. (2013). Same, same but different: Lesbian couples undergoing sperm donation (Doctoral thesis, Uppsala University, Department of Women's and Children's Health, Obstetrics and Gynaecology).

Bos, H., \& van Balen, F. (2008). Children in planned lesbian families: Stigmatisation, psychological adjustment and protective factors. Culture, Health \& Sexuality, 10(3), 221-236.

Bos, H., \& van Balen, F. (2010). Children of the new reproductive technologies: Social and genetic parenthood. Patient Education and Counseling, 81(3), 429-435.

Bos, H., van Balen, F., \& van den Boom, D. (2004). Experience of parenthood, couple relationship, social support, and childrearing goals in planned lesbian mother families. Journal of Child Psychology and Psychiatry, and Allied Disciplines, 45(4), 755-764.

Bos, H., van Balen, F., \& van den Boom, D. (2005). Lesbian families and family functioning: An overview. Patient Education and Counseling, 59(3), 263-275.

Bos, H., van Balen, F., \& van den Boom, D. (2007). Child adjustment and parenting in planned lesbian-parent families. American Journal of Orthopsychiatry, 77(1), 38-48.

Bos, H., \& Gartrell, N. (2010). Adolescents of the USA National Longitudinal Lesbian Family Study: Can family characteristics counteract the negative effects of stigmatization? Family Process, 49(4), 559-572.

Bos, H., \& Gartrell, N. (2011). Adolescents of the US National Longitudinal Lesbian Family Study: The impact of having a known or an unknown donor on the stability of psychological adjustment. Human Reproduction, 26(3), 630-637.

Bos, H., Gartrell, N., \& van Gelderen, L. (2013). Adolescents in lesbian families: DSM -oriented scale scores and stigmatization. Journal of Gay \& Lesbian Social Services, 25(2), 121-140.

Bos, H., Gelderen, L., \& Gartrell, N. (2014). Lesbian and heterosexual two-parent families: Adolescent-parent relationship quality and adolescent well-being. Journal of Child and Family Studies. 
Bos, H., Goldberg, N., van Gelderen, L., \& Gartrell, N. (2012). Adolescents of the U.S. National Longitudinal Lesbian Family Study: Male role models, gender role traits, and psychological adjustment. Gender \& Society, 26(4), 603-638.

Bos, H., \& Hakvoort, E. (2007). Child adjustment and parenting in planned lesbian families with known and as-yet unknown donors. Journal of Psychosomatic Obstetrics and Gynaecology, 28(2), 121-129.

Braun, V., \& Clarke, V. (2006). Using thematic analysis in psychology. Qualitative Research in Psychology, 3(2), 77-101.

Braun, V., \& Clarke, V. (2013). Successful qualitative research: A practical guide for beginners. London: Sage Publications Ltd.

Brewaeys, A., Ponjaert, I., van Hall, E., \& Golombok, S. (1997). Donor insemination: Child development and family functioning in lesbian mother families. Human Reproduction, 12(6), 13491359.

Brinkmann, S., \& Kvale, S. (2008). Ethics in qualitative psychology research. In C. Willig (ed.), The Sage handbook of qualitative research in psychology (pp. 263-280). London: Sage.

Brown, R., \& Perlesz, A. (2007). Not the "other" mother: How language constructs lesbian co-parenting relationships. Journal of GLBT Family Studies, 3(2-3), 267-308.

Brown, R., \& Perlesz, A. (2008). In search of a name for lesbians who mother their non-biological children. Journal of GLBT Family Studies, 4(4), 453-467.

Brown, S., Smalling, S., Groza, V., \& Ryan, S. (2009). The experiences of gay men and lesbians in becoming and being adoptive parents. Adoption Quarterly, 12(3-4), 229-246.

Burr, V. (2003). Social constructionism. London: Routledge.

Butler, J. (2006). Gender trouble: Feminism and the subversion of identity. New York: Routledge.

Buttny, R. (1993). Social accountability in communication. London: Sage.

Bäckström, L. (2006). Barn i bon: En intervjustudie med 11åringar om familj, fostran och dagligt liv (Doctoral thesis, Lund University, Department of Education).

Cameron, D., \& Kulick, D. (2003). Language and Sexuality. Cambridge: Cambridge University Press. 
Chabot, J. M., \& Ames, B. D. (2004). "It wasn't 'let's get pregnant and go do it':" Decision making in lesbian couples planning motherhood via donor insemination. Family Relations, 53(4), 348-356.

Chan, R., Brooks R., Raboy, B., \& Patterson, C. (1998).

Psychosocial adjustment among children conceived via donor insemination by lesbian and heterosexual mothers. Child Development, 69(2), 443-457.

Chapman, R., Watkins, R., Zappia, T., Combs, S., \& Shields, L. (2012). Second level hospital health professionals' attitudes to lesbian, gay, bisexual and transgender parents seeking health for their children. Journal of Clinical Nursing, 21(5-6), 880-887.

Cherguit, J., Burns, J., Pettle, S., \& Tasker, F. (2013). Lesbian comothers' experiences of maternity healthcare services. Journal of Advanced Nursing, 69(6), 1269-1278.

Choi, H., Thul, C., Berenhaut, K., Suerken, C., \& Norris, J. (2006). Survey of school psychologists' attitudes, feelings, and exposure to gay and lesbian parents and their children. Journal of Applied School Psychology, 22(1), 87-107.

Ciano-Boyce, C., \& Shelley-Sireci, L. (2002). Who is mommy tonight? Lesbian parenting issues. Journal of Homosexuality, 43(2), 1-13.

Clarke, V. (2000). "Stereotype, attack and stigmatize those who disagree": Employing scientific rhetoric in debates about lesbian and gay parenting. Feminism \& Psychology, 10(1), 152-159.

Clarke, V. (2001). What about the children? Arguments against lesbian and gay parenting. Women's Studies International Forum, 24(5), 555-570.

Clarke, V. (2002). Sameness and difference in research on lesbian parenting. Journal of Community and Applied Social Psychology, 12(3), 210-222.

Clarke, V., Kitzinger, C., \& Potter, J. (2004). "Kids are just cruel anyway": Lesbian and gay parents' talk about homophobic bullying. The British Journal of Social Psychology, 43(4), 531550.

Clarke, V. (2005). Feminist perspectives on lesbian parenting: A review of the literature 1972-2002. Psychology of Women Section Review, 7(2), 11-23. 
Clarke, V. (2008). From outsiders to motherhood to reinventing the family: Constructions of lesbian parenting in the psychological literature - 1886-2006. Women's Studies International Forum, 31(2), 118-128.

Clarke, V., Ellis, S, Peel, E. \& Riggs, D. (2010). Lesbian, gay, bisexual, trans \& queer psychology. Cambridge: University Press.

Connolly, C. (1998). The description of gay and lesbian families in second-parent adoption cases. Behavioral Sciences and the Law, 16(2), 225-236.

Crouch, S., Waters, E., McNair, R., Power, J., \& Davis, E. (2014). Parent-reported measures of child health and wellbeing in samesex parent families: A cross sectional survey. BMC Public Health, 14(1), 635.

Cummings, E. M., \& Schermerhorn, A. C. (2003). A developmental perspective on children as agents in the family. In L. Kuczynski (ed.), Handbook of dynamics in parent-child relations (pp. 91-108). Thousand Oaks: Sage.

Dahl, B., Fylkesnes, A., Sørlie, V., \& Malterud, K. (2013). Lesbian women's experiences with healthcare providers in the birthing context: A meta-ethnography. Midwifery, 29(6), 674-681.

Dahl Spidsberg, B. (2007). Vulnerable and strong: Lesbian women encountering maternity care. Journal of Advanced Nursing, $60(5), 478-486$.

Dempsey, D. (2010). Conceiving and negotiating reproductive relationships: Lesbians and gay men forming families with children. Sociology, 44(6), 1145-1162.

Dempsey, D. (2012). More like a donor or more like a father? Gay men's concepts of relatedness to children. Sexualities, 15(2), $156-174$.

DiLapi, E. (1989). Lesbian mothers and motherhood hierarchy. Journal of Homosexuality, 14(1-2), 101-121.

Donovan, C. (2000). Who needs a father? Negotiating biological fatherhood in British lesbian families using self-insemination. Sexualities, 3(2), 149-164.

Donovan, C., \& Wilson, A. (2008). Imagination and integrity: Decision-making among lesbian couples to use medically provided donor insemination. Culture, Health \& Sexuality, 10(7), 649-665. 
Downing, J., \& Goldberg, A. (2011). Lesbian mothers' constructions of the division of paid and unpaid labor. Feminism \& Psychology, 21(1), 100-120.

Duggan, L. (2004). The twilight of equality: Neoliberalism, cultural politics, and the attack on democracy. Boston, MA: Beacon Press.

Dunne, G. (2000). Opting into motherhood: Lesbians blurring the boundaries and transforming the meaning of parenthood and kinship. Gender \& Society, 14(1), 11-35.

Edley, N. (2001). Analysing masculinity: Interpretative repertoires, ideological dilemmas and subject positions. In M. Wetherell, S. Taylor, \& S. Yates (Eds.), Discourse as data: A guide for analysis (pp. 189-228). Milton Keynes, England: Open University.

Edwards, D., \& Potter, J. (1992). Discursive psychology. London: Sage.

Elliott, R., Fischer, C., \& Rennie, D. (1999). Evolving guidelines for publication of qualitative research studies in psychology and related fields. The British Journal of Clinical Psychology, 38(3), 215-229.

Epstein, R., Idems, B., \& Schwartz, A. (2013). Queer spawn on school. Confero: Essays on Education Philosophy and Politics, 1(2), 173-209.

Eriksson, M., \& Näsman, E. (2008). Intervjuer och barns delaktighet. In M. Eriksson, Å. Källström Cater, G. DahlkildÖhman, \& E. Näsman (Eds.), Barns röster om våld (pp. 42-62). Malmö: Gleerup.

Falk, P. (1989). Lesbian mothers: Psychosocial assumption in family law. American Psychologist, 44(6), 941-947.

Farr, R. H., \& Patterson, C. (2009). Transracial adoption by lesbian, gay, and heterosexual couples: Who completes transracial adoptions and with what results? Adoption Quarterly, 12(3-4), 187-204.

Fedewa, A., Black, W., \& Ahn, S. (2015). Children and adolescents with same-gender parents: A meta-analytic approach in assessing outcomes. Journal of GLBT Family Studies, 11(1), 134.

Flaks, D., Ficher, I., Masterpasqua, F., \& Joseph, G. (1995). Lesbians choosing motherhood: A comparative study of lesbian 
and heterosexual parents and their children. Developmental Psychology, 31(1), 105-114.

Foucault, M. (1972). The archaeology of knowledge and the discourse of language. London: Tavistock.

Foucault, M. (1990a). The history of sexuality. Vol. 1, The will to knowledge. Harmondsworth: Penguin.

Foucault, M. (1990b). The history of sexuality. Vol. 3, The care of the self. Harmondsworth: Penguin.

Foucault, M. (1992). The history of sexuality. Vol. 2, The use of pleasure. Harmondsworth: Penguin.

Folgerø, T. (2008). Queer nuclear families? Reproducing and transgressing heteronormativity. Journal of Homosexuality, 54(1-2), 124-149.

Frith, L., Sawyer, N., \& Kramer, W. (2012). Forming a family with sperm donation: A survey of 244 non-biological parents. Reproductive Biomedicine Online, 24(7), 709-718.

Gabb, J. (2005). Lesbian m/otherhood: Strategies of familiallinguistic management in lesbian parent families. Sociology, 39(4), 585-603.

Gartrell, N., \& Bos, H. (2010). US National Longitudinal Lesbian Family Study: Psychological adjustment of 17-year-old adolescents. Pediatrics, 126(1), 28-36.

Gartrell, N., Bos, H., \& Goldberg, N. (2011). Adolescents of the U.S. National Longitudinal Lesbian Family Study: Sexual orientation, sexual behavior, and sexual risk exposure. Archives of Sexual Behavior, 40(6), 1199-1209.

Gartrell, N., Bos, H., Goldberg, N., Deck, A., \& van Rijn-van Gelderen. (2015). Satisfaction with known, open-identity, or unknown sperm donors: Reports from lesbian mothers of 17year-old adolescents. Fertility and Sterility, 103(1), 242-248.

Gartrell, N., Bos, H., Peyser, H., Deck, A., \& Rodas, C. (2012). Adolescents with lesbian mothers describe their own lives. Journal of Homosexuality, 59(9), 1211-1229.

Gartrell, N., Deck, A., Rodas, C., Peyser, H., \& Banks, A. (2005). The National Lesbian Family Study: 4. Interviews with the 10year-old children. The American Journal of Orthopsychiatry, 75(4), 518-524.

Gartrell, N., Hamilton, J., Banks, A., Mosbacher, D., Reed, N., Sparks, C. H., \& Bishop, H. (1996). The National Lesbian 
Family Study: 1. Interviews with prospective mothers. The American Journal of Orthopsychiatry, 66(2), 272-281.

Gartrell, N., Rodas, C., Deck, A., Peyser, H., \& Banks, A. (2006).

The USA National Lesbian Family Study: Interviews with mothers of 10-year-olds. Feminism \& Psychology, 16(2), 175192.

van Gelderen, L., Gartrell, N., Bos, H., van Rooij, F., \& Hermanns,

J. (2012). Stigmatization associated with growing up in a lesbian-parented family: What do adolescents experience and how do they deal with it? Children and Youth Services Review, 34(5), 999-1006.

Gianino, M., Goldberg, A., \& Lewis, T. (2009). Family outings:

Disclosure practices among adopted youth with gay and lesbian parents. Adoption Quarterly, 12(3-4), 205-228.

Goldberg, A. (2007). Talking about family: Disclosure practices of adults raised by lesbian, gay, and bisexual parents. Journal of Family Issues, 28(1), 100-131.

Goldberg, A. (2009). Lesbian and heterosexual preadoptive couples' openness to transracial adoption. The American Journal of Orthopsychiatry, 79(1), 103-117.

Goldberg, A. (2014). Will I marry if my parents can't? Young adults with LGB parents consider marriage for themselves. Journal of Family Issues, 35(2), 151-180.

Goldberg, A., \& Allen, K. (2013a). Donor, dad, or...? Young adults with lesbian parents' experiences with known donors. Family Process, 52(2), 338-350.

Goldberg, A., \& Allen, K. (2013b). Same-sex relationship dissolution and LGB stepfamily formation: Perspectives of young adults with LGB parents. Family Relations, 62(4), 529544.

Goldberg, A., Downing, J., \& Sauck, C. (2007). Choices, challenges, and tensions. Adoption Quarterly, 10(2), 33-64.

Goldberg, A., Downing, J., \& Sauck, C. (2008). Perceptions of children's parental preferences in lesbian two-mother households. Journal of Marriage and Family, 70(2), 419-434.

Goldberg, A., Kashy, D., \& Smith, J. (2012). Gender-typed play behavior in early childhood: Adopted children with lesbian, gay, and heterosexual parents. Sex Roles, 67(9-10), 503-515. 
Goldberg, A., Kinkler, L. Richardson, H., \& Downing, J. (2012b).

On the border: Young adults with LGBQ parents navigate LGBTQ communities. Journal of Counseling Psychology, 59(1), $71-85$.

Goldberg, A., Moyer, A., Kinkler, L., \& Richardson, H. (2012). "When you're sitting on the fence, hope's the hardest part": Challenges and experiences of heterosexual and same-sex couples adopting through the child welfare system. Adoption Quarterly, 15(4), 288-315.

Goldberg, A., \& Perry-Jenkins, M. (2007). The division of labor and perceptions of parental roles: Lesbian couples across the transition to parenthood. Journal of Social and Personal Relationships, 24(2), 297-318.

Goldberg, A., \& Smith, J. (2011). Stigma, social context, and mental health: Lesbian and gay couples across the transition to adoptive parenthood. Journal of Counseling Psychology, 58(1), 139-150.

Goldberg, A., Smith, J., \& Perry-Jenkins, M. (2012a). The division of labor in lesbian, gay, and heterosexual new adoptive parents. Journal of Marriage and Family, 74(4), 812-828.

Goldberg, A., Weber, E., Moyer, A., \& Shapiro, J. (2014). Seeking to adopt in Florida: Lesbian and gay parents navigate the legal process. Journal of Gay \& Lesbian Social Services, 26(1), 3769.

Golombok, S., \& Badger, S. (2010). Children raised in motherheaded families from infancy: A follow-up of children of lesbian and single heterosexual mothers, at early adulthood. Human Reproduction, 25(1), 150-157.

Golombok, S., Spencer, A., \& Rutter, M. (1983). Children in lesbian and single-parent households: Psychosexual and psychiatric appraisal. Journal of Child Psychology and Psychiatry, and Allied Disciplines, 24(4), 551-572.

Golombok, S., Tasker, F., \& Murray, C. (1997). Children raised in fatherless families from infancy: Family relationships and the socioemotional development of children of lesbian and single heterosexual mothers. Journal of Child Psychology and Psychiatry and Allied Disciplines, 38(7), 783-791.

Gubrium, J., \& Holstein, J. (Eds.) (2006). Couples, kids, and family life. New York: Oxford University Press. 
Gustavson, M., \& Schmitt, I. (2011) Culturally queer, silenced in school? Children with LGBTQ parents and the everyday politics of/in community and school. Lambda Nordica, 16(2-3), 159187.

Halldén, G. (2007). Barndomssociologi och möjligheten av ett psykosocialt perspektiv. In: G. Halldén (ed.), Den moderna barndomen och barns vardagsliv (pp. 25-40). Stockholm: Carlsson Bokförlag.

Hansen Orwehag, M. (2013). Barnintervjun - ur barnperspektiv och barns perspektiv. In S. Erlandsson \& L. Sjöberg (Eds.), Barn och ungdomsforskning: Metoder och arbetssätt (pp. 157177). Lund: Studentlitteratur.

Hayman, B., Wilkes, L., Halcomb, E., \& Jackson, D. (2013). Marginalised mothers: Lesbian women negotiating heteronormative healthcare services. Contemporary Nurse, 44(1), 120-127.

Hegde, A., Averett, P., Parker White, C., \& Deese, S. (2013). Examining preschool teachers' attitudes, comfort, action orientation and preparation to work with children reared by gay and lesbian parents. Early Child Development and Care, 184(7), 963-976.

Henriques, J., Hollway, W., Urwin, C., Venn, C., \& Walkerdine, V. (1984/1998). Changing the subject: Psychology, social regulation and subjectivity. New York: Routledge.

Herbstrith, J., Tobin, R., Hesson-McInnis, M., \& Schneider, W. (2013). Preservice teacher attitudes toward gay and lesbian parents. School Psychology Quarterly, 28(3), 183-194.

Herrera, F. (2009). Tradition and transgression: Lesbian motherhood in Chile. Sexuality Research and Social Policy, $6(2), 35-51$.

Hicks, S. (2005). Is gay parenting bad for kids? Responding to the "very idea of difference" in research on lesbian and gay parents. Sexualities, 8(2), 153-168.

Hicks, S. (2011). Lesbian, gay and queer parenting. Hampshire: Palgrave Macmillian.

Hollekim, R., Slaatten, H., Anderssen, N. (2012). A nationwide study of Norwegian beliefs about same-sex marriage and lesbian and gay parenthood. Sex Res Soc Policy, 9, 15-30. 
Holli, A., Magnusson, E., \& Rönnblom, M. (2005). Critical studies of Nordic discourses on gender and gender equality. NORA Nordic Journal of Women's Studies, 13(3), 148-152.

Holt, A. (2011). Discourse analysis approaches. In N. Frost (ed.), Qualitative Research Methods in Psychology (pp. 66-91). Berkshire: Open University Press.

Howitt, D. (2010). Introduction to qualitative methods in psychology. Harlow, England: Financial Times Prentice Hall. Hunleth, J. (2011). Beyond on or with: Questioning power dynamics and knowledge production in "child-oriented" research methodology. Childhood, 18(1), 81-93.

Hunt Federle, K. (2005). When second parent adoption is not an option. Adoption Quarterly, 9(1), 79-86.

Hurd, T., \& McIntyre, A. (1996). The seduction of sameness: Similarity and representing the other. In S. Wilkinson \& C. Kitzinger (Eds.), Representing the other (pp. 78-82). London: Sage Publications.

Institutionen för pedagogik, kommunikation och lärande. (2012, 05 September). Per Nordén. Retrieved from http://ipkl.gu.se/omipkl/personal? userId $=$ xstrpe

Jadva, V., Freeman, T., Kramer, W., \& Golombok, S. (2010). Experiences of offspring searching for and contacting their donor siblings and donor. Reproductive BioMedicine Online, 20(4), 523-532.

James, A., \& James, A. (2008). Key concepts in childhood studies. London: Sage.

James, A., Jenks, C., \& Prout, A. (1998). Theorizing childhood. Cambridge: Polity Press.

Johansson, B. (2013). Kvalitativ barndomsforskning. In B. Johansson \& M. Karlsson (Eds.), Att involvera barn i forskning och utveckling (pp. 27-36). Lund: Studentlitteratur.

Johansson, B., \& Karlsson, M. (2013). Inledning. In B. Johansson \& M. Karlsson (Eds.), Att involvera barn i forskning och utveckling (pp. 11-26). Lund: Studentlitteratur.

Johansson, T., \& Klinth, R. (2008). Caring fathers: The ideology of gender equality and masculine positions. Men and Masculinities, 11(1), 42-62.

Kawash, S. (2011). New directions in motherhood studies. Signs: Journal of Women in Culture and Society, 36(4), 969-1003. 
Kellett, M. (2010). Rethinking children and research, attitudes in contemporary society. London: Continuum International publishing group.

Kessler, S., \& McKenna, W. (1985). Gender: An ethnomethodological approach. Chicago: University of Chicago Press.

Killian, M. (2010). The political is personal: Relationship recognition policies in the United States and their impact on services for LGBT people. Journal of Gay \& Lesbian Social Services, 22(1-2), 9-21.

Kinkler, L., \& Goldberg, A. (2011). Working with what we've got: Perceptions of barriers and supports among small-metropolitanarea same-sex adopting couples. Family Relations, 60(4), 387403.

Kitzinger, C. (2005). Heteronormativity in action: Reproducing the heterosexual nuclear family in after-hour medical calls. Social Problems, 52(4), 477-498.

Kitzinger, C. (2006). After post-cognitivism. Discourse Studies, $8(1), 67-83$.

Kitzinger, C. (2009). Doing Gender: A conversation analytic perspective. Gender \& Society, 23(1), 94-98.

Kitzinger, C., \& Wilkinson, S. (1996). Theorizing representing the Other. In S. Wilkinson \& C. Kitzinger (Eds.), Representing the other (pp. 1-32). London: Sage Publications.

Kulick, D. (1996). Queer theory: Vad är det och vad är det bra för? Lambda Nordica, 2(2-3), 5-22.

Kuvalanka, K., Leslie, L., \& Radina, R. (2014). Coping with sexual stigma: Emerging adults with lesbian parents reflect on the impact of heterosexism and homophobia during their adolescence. Journal of Adolescent Research, 29(2), 241-270.

Land, V., \& Kitzinger, C. (2005). Speaking as a lesbian :

Correcting the heterosexist presumption. Research on Language and Social Interaction, 38(4), 371-416.

Larsson, A-K., \& Dykes, A-K. (2009). Care during pregnancy and childbirth in Sweden: Perspectives of lesbian women. Midwifery, 25(6), 682-690.

Lee, E., Taylor, J., \& Raitt, F. (2011). “It's not me, it's them”: How lesbian women make sense of negative experiences of maternity 
care: A hermeneutic study. Journal of Advanced Nursing, 67(5), 982-990.

Letherby, G. (2003). Feminist research in theory and practice. Buckingham: Open University Press.

Lick, D., Patterson, C., \& Schmidt, K. (2013). Recalled social experiences and current psychological adjustment among adults reared by gay and lesbian parents. Journal of GLBT Family Studies, 9(3), 230-253.

Lubbe, C. (2008). The experiences of children growing up in lesbian-headed families in South Africa. Journal of GLBT Family Studies, 4(3), 325-359.

McManus, A., Hunter, L., \& Renn, H. (2006). Lesbian experiences and needs during childbirth: Guidance for health care providers. JOGNN - Journal of Obstetric, Gynecologic, and Neonatal Nursing, 35(1), 13-23.

McNair, R., Brown, R., Perlesz, A., Lindsay, J., De Vaus, D., \& Pitts, M. (2008). Lesbian parents negotiating the health care system in Australia. Health Care for Women International, 29(2), 91-114.

Magnusson, E. (2006). Hon, han och hemmet. Stockholm: Natur och Kultur.

Magnusson, E. (2008). The rhetoric of inequality: Nordic women and men argue against sharing house-work. NORA - Nordic Journal of Feminist and Gender Research, 16(2), 79-95.

Mallon, G. (2011). The home study assessment process for gay, lesbian, bisexual, and transgender prospective foster and adoptive families. Journal of GLBT Family Studies, 7(1-2), 929.

Malmquist, A. (forthcoming). Swedish lesbian mothers arrange parental leave: The heteronormative, homonormative and unnormative way. To be submitted.

Malmquist, A., Gustavson, M., \& Schmitt, I. (2013). Queering school, queers in school: An introduction. Confero: Essays on Education Philosophy and Politics, 1(2), 5-15.

Malmquist, A., Polski, A., \& Zetterqvist Nelson, K. (forthcoming). No one of importance: Mothers in lesbian relations talk about permanently anonymous sperm donors.

Malmquist, A., \& Zetterqvist Nelson, K. (2008). Diskursiv diskriminering av regnbågsfamiljer: En analys av argument mot 
likställande av homo- och heterosexuellas föräldraskap. Socialvetenskaplig Tidskrift, 15(3-4), 315-331.

Malmquist, A., \& Zetterqvist Nelson, K. (2013). Gay and lesbian parents. In H. Montgomery (ed.), Oxford bibliographies in childhood studies (p. 1-18). New York, NY: Oxford University Press.

Marina, S., Marina, D., Marina, F., Fosas, N., Galiana, N., \& Jove', I. (2010). Sharing motherhood: Biological lesbian co-mothers, a new IVF indication. Human Reproduction 25(4), 930-941.

Mezey, N. (2008). New choices, new families, how lesbians decide about motherhood. Baltimore: John Hopkins University Press.

Morgan, D. (1996). Family connections. Cambridge: Polity Press.

Morgan, D. (2011). Rethinking family practices. Basingstoke: Palgrave Macmillan.

Morrow, V. (1998) Understanding families: Children's perspectives. London: National Children's Bureau.

Morse, C. N., McLaren, S., \& McLachlan, A. J. (2007). The attitudes of Australian heterosexuals toward same-sex parents. Journal of GLBT Family Studies, 3(4), 425-455.

Möllerstrand, A., \& Wikström, M. (2011). En familj är att man är bra ihop: En diskursanalytisk studie av regnbågsbarns prat om familj och tillblivelse (Master's thesis, Linköping University, Department of Behavioural Sciences and Learning).

Newman, J. L., Roberts, L. R., \& Syré, C. R. (1993). Concepts of family among children and adolescents: Effect of cognitive level, gender, and family structure. Developmental Psychology, 29(6), 951-962.

Nicol, P., Chapman, R., Watkins, R., Young, J., \& Shields, L. (2013). Tertiary paediatric hospital health professionals' attitudes to lesbian, gay, bisexual and transgender parents seeking health care for their children. Journal of Clinical Nursing, 22(23-24), 3396-3405.

Nordqvist, P. (2012). Origins and originators : Lesbian couples negotiating parental identities and sperm donor conception. Culture, Health \& Sexuality, 14(3), 297-311.

Nordqvist, P. (2014). Bringing kinship into being: Connectedness, donor conception and lesbian parenthood. Sociology, 48(2), 268-283. 
Oerton, S. (1997). “Queer housewives?": Some problems in theorising the division of domestic labour in lesbian and gay households. Women's Studies International Forum, 20(3), 421430.

Oliveira-Formosinho, J. (2009). Togetherness and play under the same roof: Children's perceptions about families. European Early Childhood Education Research Journal, 17(2), 233-248.

Oswald, R. F., \& Lazarevic, V. (2011). "You live where?!" Lesbian mothers' attachment to nonmetropolitan communities. Family Relations, 60(4), 373-386.

Ottosson, P. (2015, 26 January). Inga homoadoptioner på över tio år trots svensk lag. $Q X$. Retrieved from http://www.qx.se/samhalle/28079/inga-homoadoptioner-paover-tio-ar-trots-svensk-lag

Padavic, I., \& Butterfield, J. (2011). Mothers, fathers, and "mathers": Negotiating a lesbian co-parental identity. Gender \& Society, 25(2), 176-196.

Patterson, C. (1992). Children of lesbian and gay parents. Child Development, 63(5), 1025-1042.

Patterson, C. (1995). Families of the baby boom: Parents' division of labor and children's adjustment. Developmental Psychology, 31(1), 115-123.

Patterson, C., Sutfin, E., \& Fulcher, M. (2004). Division of labor among lesbian and heterosexual parenting couples: Correlates of specialized versus shared patterns. Journal of Adult Development, 11(3), 179-189.

Peel, E. (2010). Pregnancy loss in lesbian and bisexual women: An online survey of experience. Human Reproduction, 25(3), 721727.

Pelka, S. (2009). Sharing motherhood: Maternal jealousy among lesbian co-mothers. Journal of Homosexuality, 56(2), 195-217.

Perlesz, A., Power, J., Brown, R., McNair, R., Schofleld, M., Pitts, M., ... Bickerdike, A. (2010). Organising work and home in same-sex parented families: Findings from the Work Love Play Study. The Australian and New Zealand Journal of Family Therapy, 31(4), 374-391.

Polski, A. (2013). Ingen av betydelse: Mödrar från samkönad familjebildning talar om spermadonatorn. (Master's thesis, Lund University, Department of Psychology). 
Potter, D. (2012). Same-sex parent families and children's academic achievement. Journal of Marriage and Family, 74(3), $556-571$

Potter, J. (1996). Representing reality: Discourse, rhetoric and social construction. London: Sage.

Potter, J. (2012a). How to study experience. Discourse \& Society, 23(5), 576-588.

Potter, J. (2012b). Re-reading discourse and social psychology: Transforming social psychology. The British Journal of Social Psychology, 51(3), 436-455.

Potter, J., \& Wetherell, M. (1987). Discourse and social psychology. London: Sage.

Proposition 2001/02:123. Partnerskap och adoption.

Proposition 2004/05:137. Assisterad befruktning och föräldraskap. Puckett, J., Horne, S., Levitt, H., \& Reeves, T. (2011). Out in the country: Rural sexual minority mothers. Journal of Lesbian Studies, 15(2), 176-186.

Regnerus, M. (2012). How different are the adult children of parents who have same-sex relationships? Findings from the New Family Structures Study. Social Science Research, 41(4), $752-770$.

Rejmer, A. (2003). Vårdnadstvister: En rättssociologisk studie av tingsrätts funktion vid handläggning av vårdnadskonflikter med utgångspunkt från barnets bästa (Doctoral thesis, Lund University, Department of Sociology).

Rigg, A., \& Pryor, J. (2006). Children's perceptions of Families: What do they really think? Children \& Society, 21(1), 17-30. Riggs, D., \& Willing, I. (2013). “They're all just little bits, aren't they": South Australian lesbian mothers' experiences of marginalisation in primary schools. Journal of Australian Studies, 37(3), 364-377.

van Rijn-van Gelderen, L., Bos, H., \& Gartrell, N. (2015). Dutch adolescents from lesbian-parent families: How do they compare to peers with heterosexual parents and what is the impact of homophobic stigmatization? Journal of Adolescence, 40, 65-73. Ritenhouse, D. (2011). What's orientation got to do with it?: The best interest of the child standard and legal bias against gay and lesbian parents. Journal of Poverty, 15(3), 309-329. 
Rivers, D. (2010). "In the best interests of the child": Lesbian and gay parenting custody cases, 1967-1985. Journal of Social History, 43(4), 917-943.

Robinson, B. A. (2012). Is this what equality looks like? Sexuality Research and Social Policy, 9(4), 327-336.

Ross, L., Epstein, R., Anderson, S., \& Eady, A. (2009). Policy, practice, and personal narratives: Experiences of LGBTQ people with adoption in Ontario, Canada. Adoption Quarterly, 12(3-4), 272-293.

Ross, L., Epstein, R., Goldfinger, C., Steele, L., Anderson, S., \& Strike, C. (2008). Lesbian and queer mothers navigating the adoption system: The impacts on mental health. Health Sociology Review, 17(3), 254-266.

Rozental, A. (2011). Möjligheter och förbehåll: En diskursanalytisk studie av lesbiska kvinnors erfarenheter av att bilda familj genom assisterad befruktning inom svensk sjukvård (Master's thesis, Linköping University, Department of Behavioural Sciences and Learning).

Ryan, M. (2013). The gender of pregnancy: Masculine lesbians talk about reproduction. Journal of Lesbian Studies, 17(2), 119-133.

Ryan, M., \& Berkowitz, D. (2009). Constructing gay and lesbian parent families "beyond the closet." Qualitative Sociology, $32(2), 153-172$.

Ryan, S., \& Whitlock, C. (2007). Becoming parents: Lesbian mothers' adoption experience. Journal of Gay \& Lesbian Social Services: Issues in Practice, Policy \& Research, 19(2), 1-23.

Ryan-Flood, R. (2005). Contested heteronormativities: Discourses of fatherhood among lesbian parents in Sweden and Ireland. Sexualities, 8(2), 189-204.

Ryan-Flood, R. (2009). Lesbian motherhood: Gender, families and sexual citizenship. Basingstoke: Palgrave Macmillan.

Röndahl, G. (2005). Heteronormativity in a nursing context: Attitudes toward homosexuality and experiences of lesbians and gay men (Doctoral thesis, Uppsala University, Department of Public Health and Caring Sciences).

Röndahl, G., Bruhner, E., \& Lindhe, J. (2009). Heteronormative communication with lesbian families in antenatal care, childbirth and postnatal care. Journal of Advanced Nursing, 65(11), 2337-2344. 
Schiratzki, J. (2008). Mamma och pappa inför rätta. Uppsala: Iustus.

Scott, J. (2008). Children as respondents: The challenge for qualitative methods. In P. Christensen \& A. James (Eds.), Research with children, perspectives and practices (pp.87-108). Oxon: Routledge.

Scott, M. B., \& Lyman, S. M. (1968). Accounts. American

Sociological Review, 33(1), 46-62.

SFS 1949:381 Föräldrabalk.

SFS 1987:230 Äktenskapsbalk.

SFS 1994:1117. Lag om registrerat partnerskap.

SFS 2003:460. Lag om etikprövning av forskning som avser människor.

SFS 2006:351. Lag om genetisk integritet m.m.

Shechner, T., Slone, M., Lobel, T. E., \& Shechter, R. (2013).

Children's adjustment in non-traditional families in Israel: The effect of parental sexual orientation and the number of parents on children's development. Child: Care, Health and Development, 39(2), 178-84.

Scheib, J., Riordan, M., \& Rubin, S. (2005). Adolescents with open-identity sperm donors: Reports from 12-17 year olds. Human Reproduction, 20(1), 239-252.

Shields, L., Zappia, T., Blackwood, D., Watkins, R., Wardrop, J., \& Chapman, R. (2012). Lesbian, gay, bisexual, and transgender parents seeking health care for their children: A systematic review of the literature. Worldviews on Evidence-Based Nursing, 9(4), 200-209.

Short, L. (2007). Lesbian mothers living well in the context of heterosexism and discrimination: Resources, strategies and legislative change. Feminism \& Psychology, 17(1), 57-74. Silva, E., \& Smart, C. (1999). The new family? London: Sage. Smith, D. (1993). The Standard North American Family: SNAF as an ideological code. Journal of Family Issues, 14(1), 50-65.

Sobočan, A. (2013). Two dads / two moms: Defying and affirming the mom-dad family. The case of same-gender families in Slovenia. Confero: Essays on Education Philosophy and Politics, 1(2), 90-122.

SOU 2001:10. Barn i homosexuella familjer. Stockholm: Fritzes offentliga publikationer. 
Speer, S. \& Potter, J. (2000). The management of heterosexist talk: Conversational resources and prejudiced claims. Discourse \& Society, 11(4), 543-572.

Spidsberg, B. D., \& Sørlie, V. (2012). An expression of love: Midwives' experiences in the encounter with lesbian women and their partners. Journal of Advanced Nursing, 68(4), 796805.

Sprague, J. (2005). Feminist Methodologies for Critical Researchers: Bridging Differences. Walnut Creek: Alta Mira Press.

Stacey, J., \& Biblarz, T. (2001). (How) does the sexual orientation of parents matter? American Sociological Review, 66(2), 159 183.

Statistiska centralbyrån. (2013, 31 December). Befolkningsstatistik. Retrieved from http://www.scb.se/sv_/Hitta-statistik/Statistikefter-amne/Befolkning/Befolkningenssammansattning/Befolkningsstatistik/25788/25795/Helarsstatisti k---Kommun-lan-och-riket/370301/

Streib-Brziĉ, U., \& Quadflied, C. (Eds.). (2012). 'School is out'. Comparative study. Experiences of Children from Rainbowfamilies in Germany, Sweden, and Slovenia. Zentrum für transdisziplinare Geschlechterstudien an der HumboldtUniversität zu Berlin.

Sverige Statistiska centralbyrån, enheten för befolkningsstatistik. (2012). På tal om kvinnor och män: Lathund om jämställdhet 2012. Stockholm: Statistiska centralbyrån.

Swedish Social Insurance Agency. (2012). Parental benefit. Retrieved from http://www.forsakringskassan.se

Tasker, F., \& Golombok, S. (1998). The role of co-mothers in planned lesbian-led families. Journal of Lesbian Studies, 2(4), 49-68.

Tasker, F., \& Granville, J. (2011). Children's views of family relationships in lesbian-led families. Journal of GLBT Family Studies, 7(1-2), 182-199.

Tobin, J., \& McNair, R. (2008). Public international law and the regulation of private spaces: Does the convention on the rights of the child impose obligation on states to allow gay and lesbian couples to adopt? International Journal of Law, Policy and the Family, 23(1), 110-131. 
Tornello, S., Johnson, S., \& O’Connor, E. (2013). Relationship quality among lesbian mothers in planned families. Journal of GLBT Family Studies, 9(4), 346-363.

Vanfraussen, K., Ponjaert-Kristoffersen, I., \& Brewaeys, A. (2001). An attempt to reconstruct children's donor concept: A comparison between children's and lesbian parents' attitudes towards donor anonymity. Human Reproduction, 16(9), 20192025.

Vanfraussen, K., Ponjaert-Kristoffersen, I., \& Brewaeys, A. (2002). What does it mean for youngsters to grow up in a lesbian family created by means of donor insemination? Journal of Reproductive and Infant Psychology, 20(4), 237-252.

Vanfraussen, K., Ponjaert-Kristoffersen, I., \& Brewaeys, A. (2003).

Why do children want to know more about the donor? The experience of youngsters raised in lesbian families. Journal of Psychosomatic Obstetrics and Gynaecology, 24(1), 31-38.

Vetenskapsrådet. (2002). Forskningsetiska principer inom humanistisk-samhällsvetenskaplig forskning. Stockholm: Vetenskapsrådet.

Wall, M. (2013). Lesbians' perceived readiness to parent. Affilia, 28(4), 391-400.

Ward, J. (2008). Dude-sex: White masculinities and 'authentic' heterosexuality among dudes who have sex with dudes. Sexualities, 11(4), 414-434.

Warner, M. (1999). The trouble with normal: Sex, politics and the ethics of queer life. New York: Free Press.

Weeks, J., Heaphy, B., \& Donovan, C. (2001). Same sex intimacies: Families of choice and other life experiments. London: Routledge.

West, C., \& Zimmermann, D. (1987). Doing gender. Gender \& Society, 1, 121-151.

Weston, K. (1991). Families we choose: Lesbians, gays, kinship. New York: Columbia University Press.

Wetherell, M. (1998). Positioning and interpretative repertoires: Conversation analysis and post-structuralism in dialogue. Discourse \& Society, 9(3), 387-412.

Wetherell, M. (2007). A step too far: Discursive psychology, linguistic ethnography and questions of identity. Journal of Sociolinguistics, 11(5), 661-681. 
Wetherell, M., \& Potter, J. (1992). Mapping the language of racism. New York: Columbia University Press.

Willig, C. (2008). Introducing qualitative research in psychology. Buckingham: Open university press.

Wilton, T., \& Kaufmann, T. (2001). Lesbian mothers' experiences of maternity care in the UK. Midwifery, 17(3), 203-211.

Wojnar, D., \& Katzenmeyer, A. (2014). Experiences of preconception, pregnancy, and new motherhood for lesbian nonbiological mothers. Journal of Obstetric, Gynecologic, and Neonatal Nursing, 43(1), 50-60.

Woodford, M., Sheets, K., Scherrer, K., D'Eon-Blemings, R., Tenkate, I., \& Addams, B. (2010). Lesbian adoptive couples: Responding to shifting identities and social relationships. Affilia, 25(3), 278-290.

Woodhead, M., \& Faulkner, D. (2008). Subjects, objects or participants? Dilemmas of psychological research with children. In P. Christensen \& A. James (Eds.), Research with children: Perspectives and practices (pp.10-39). Oxon: Routledge.

Wyness, M. G. (2012). Childhood and society. Basingstoke: Palgrave Macmillan.

Zeiler, K., \& Malmquist, A. (2014). Lesbian shared biological motherhood: The ethics of IVF with reception of oocytes from partner. Medicine, Health Care and Philosophy, 17(3), 347-355. Zetterqvist Nelson, K. (2006). Att vara pappa i homofamiljer: Berättelser om barn, mammor och familjeliv. Socialvetenskaplig Tidskrift, (1), 66-86.

Zetterqvist Nelson, K. (2007). Mot alla odds: Regnbågsföräldrars berättelser om att bilda familj och få barn. Malmö: Liber.

Zetterqvist Nelson, K., \& Malmquist, A. (2011). Assisterad befruktning för lesbiska par: Gayvänligt, heteronormativt eller både och? In H. Bergman, M. Eriksson, \& R. Klinth (Eds.), Föräldraskapets politik: Från 1900-tal till 2000-tal (pp. 129150). Stockholm: Dialogos förlag. 


\section{Sammanfattning på svenska}

För lesbiska par har förutsättningarna för föräldraskap förändrats $i$ grunden sedan millennieskiftet. År 2003 möjliggjorde en lagändring att ett barn kan ha två rättsliga föräldrar av samma kön, något som dessförinnan inte tillåtits. Ytterligare en lagändring öppnade år 2005 möjligheten för lesbiska par att få barn genom assisterad befruktning inom svensk sjukvård. I avhandlingen fokuseras familjer som bildats med stöd av dessa båda lagändringar, familjer där två kvinnor delar det rättsliga föräldraskapet om sina gemensamma barn. Avhandlingen syftar till att bredda kunskaper om lesbiska familjeliv och fokuserar samspelet mellan familjemedlemmar såväl som samspelet mellan familjen och dess omgivning. Vidare syftar avhandlingen till att synliggöra och analysera uttryck för heteronormativitet och homonormativitet i dagens Sverige. Avhandlingen tar avstamp i familjernas egna berättelser, beskrivningar, reflektioner och diskurser, där föräldrarnas och barnens röster granskas i detalj.

Avhandlingen består av fem empiriska artiklar och en kappa. Artikel I, II och III baseras på intervjuer med 96 föräldrar i 51 familjer. Samtliga deltagare var föräldrar till ett eller två barn som fötts inom ramen för en lesbisk kärleksrelation. I Artikel I analyseras föräldrarnas berättelser om att möta sjukvården i samband med graviditet och förlossning. Dessa berättelser har analyserats med en diskurspsykologisk ansats. I resultatet framträder två former av berättelser, så kallade tolkningsrepertoarer. Dels konstrueras en tolkningsrepertoar om det varma och positiva mötet med engagerad och omtänksam vårdpersonal och dels konstrueras en tolkningsrepertoar om heteronormativa svårigheter, där föräldrarna uttrycker att vårdpersonal är fördomsfulla eller okunniga i mötet med dem som lesbisk familj. Intressant nog återfinns båda dessa tolkningsrepertoarer i flertalet av intervjuerna. I analysen visas hur 
intervjupersonerna växlar mellan de båda repertoarerna, på ett sätt som tonar ner och slätar över svårigheter till förmån för den dominerande berättelsen om att allt varit "bara bra".

I Artikel II används en tematisk analys för att belysa deltagarnas berättelser om närståendeadoption. För att kunna dela rättsligt föräldraskap med varandra som två kvinnor krävs i många fall en närståendeadoption, där den biologiska mammans partner adopterar barnet. Artikeln visar hur föräldrarna beskriver adoptionen som oerhört betydelsefull för deras familjebildning och vardagsliv. Själva adoptionsprocessen beskrivs dock i kritiska ordalag av många intervjupersoner som menar att utredningen som föregår adoptionen är för omfattande och tar för lång tid. I flera intervjuer framställs de socialarbetare som genomför utredningen som oprofessionella, då de beskrivs ställa irrelevanta eller närgångna frågor vilka ofta speglar en heteronormativ idealbild av familjeliv. Andra beskriver dock socialarbetare som kompetenta och trevliga.

I Artikel III fokuseras relationen mellan föräldrarna. Med hjälp av en diskurspsykologisk ansats granskas hur föräldrarna pratar om jämställdhet i sina föräldraroller. Tre olika tolkningsrepertoarer framträdde i intervjuerna. I den första repertoaren presenterar föräldrarna sig som jämställda och framställer det som självklart för dem dela en gemensam, unison föräldraroll. I den andra repertoaren beskrivs en skillnad mellan föräldrarna, där den som fött barnet anses få en primär föräldraroll och den som inte fött barnet får en sekundär roll. Här ses jämställdhet som ett potentiellt resultat av hårt arbete, jämställdhet är något de uppnår genom strävan. Slutligen, $\mathrm{i}$ den tredje repertoaren, framställs det som en självklar utgångspunkt att den biologiska mamman är den primära föräldern, och jämställda föräldraroller ses inte som något eftersträvansvärt. Analysen visar hur såväl jämställdhetsideal som betydelsen av biologiska band används som retoriska verktyg för att stärka berättelsen om familjen.

Artikel IV är en tematisk analys av intervjuer med 29 kvinnor i 16 lesbiska familjer som alla vänt sig till svensk sjukvård för fertilitetsbehandling. Studien visar hur kvinnorna beskriver sig själva som sårbara, dels i förhållande till sjukvårdens heteronormativa föreställningar om familjer och dels $i$ den utsatthet 
som patientrollen medför. Sjukvårdens rutiner och behandlingsupplägg är inte anpassade till de samkönade parens behov. Samtidigt som intervjupersonerna ger uttryck för brister i såväl bemötande som behandlingsupplägg, ger de också uttryck för en acceptans av rådande omständigheter. De uttrycker en tacksamhet över att överhuvudtaget vara inkluderade i landstingens fertilitetsprogram, vilket retoriskt tonar ner uttrycken för missnöje.

Slutligen, i Artikel V, är det barnen som står i fokus. Studien bygger på intervjuer med tolv barn i elva familjer. Deltagarna var mellan fem och åtta år gamla och växer upp i familjer med två mammor. Barnen ger i intervjuerna sina bilder av vad en familj är för något och hur barn blir till. I artikeln har barnens beskrivningar av pappor och spermadonatorer granskats och presenteras i en tematisk analys. Flera av barnen uttrycker att det är svårt - för den som inte själv har en pappa - att beskriva vad en pappa är. De flesta barnen uttrycker dock att en pappa är "samma sak" som en mamma, och flera barn beskriver pappor som vuxna som tar hand om barn. När barnen pratar om hur de själva blivit till har de olika sätt att benämna spermadonatorn. Några barn pratar om honom som "en man", medan andra använder uttrycket "fröpappa" eller bara "pappa". Att å ena sidan prata om en spermadonator som "pappa", men å andra sidan inte ha någon pappa i relationell mening, ger i vissa fall upphov till en rörig berättelse. 


\section{Acknowledgements}

First and foremost, I wish to direct a tremendous thank you to the children and parents who participated in the studies. Thank you truly for sharing your reflections, experiences and insights with me and my fellow researchers. Thank you for the trust you put in us by letting us study your narratives.

This work would not have been possible without the excellent support, encouragement and engagement of my main supervisor, Professor Karin Zetterqvist Nelson. Karin believed in me from the start and put huge trust in me when deciding to find funding for our research project. For this, I am more grateful than I am able to express in words. Thank you, Karin, for thousands of valuable comments, supportive pep talks and for trusting me to make my own decisions in the end.

I also owe a great thank you to my second supervisor, Associate Professor Kristin Zeiler. Kristin, thank you for your sharp comments on my texts, and for enabling alternative perspectives when Karin and I have disagreed. I particularly enjoyed writing an article together with you and benefited from your energy and engagement.

Four Master's students have contributed significantly to my research. Anna Möllerstrand, Anna Polski, Alexander Rozental and Maria Wikström, a huge thank you for your engagement, brilliant analysis and texts. It has been a pleasure working with each one of you. Recently, I have been fortunate to also include Maria Bergqvist in the research project, with her forthcoming Bachelor's thesis. I enjoy working with you, and look forward to seeing your results soon. 
Five students also contributed to the thesis by transcribing the interview data. Thank you Lukas Eriksson, Erik Nilsson, Maria Nilsson, Katarina Tagesson and Henrik Wallénius. For proofreading all my texts, and for brilliant translation of all interview quotes, I owe a huge thank you to Karen Williams.

As a doctoral student I have my academic residence at the Department of Behavioural Science and Learning, Linköping University, Sweden. More than at any other workplace, I have found myself feeling at home in academia. I have met an open-minded space in the university, where different opinions and experiences are met with interest and curiosity.

I wish to express my gratitude to all my present and former colleagues, students and friends at the department. My colleagues mainly engage in research fields and methods very different from my own, and I have sometimes felt like a satellite at the department. Therefore, I am particularly thankful to those of you who put an extra effort into making me feel included. Special thanks to:

Lars Back, for giving me the freedom to form my own time and place at the department. Thank you for your excellent support when I came back to work after sick leave.

Ulrika Birberg Thornberg, for your strength and openness. Your friendship and support after Myran's death was absolutely invaluable. Thank you so much!

Eva Hammar Chiriac, for trusting me in co-supervising our many Master's students. I always feel confident with you as a back-up reader. Thank you for always including me in the social psychology group.

Sofia Johnson Frankenberg, for good talks and shared laughter, especially during the time we shared an office.

Gunvor Larsson Abbad, thank you for being Gunvor, basically. Thank you for your wonderful humour and big heart. 
Erika Viklund, for your dystopic humour and for coming to my rescue whenever I have been too distracted to do things right.

Lise Bergman Nordgren, Gisela Eckert, Teddy Fredriksson, Anneli Frostell, Elisabeth Ingo, Malin Gren Landell, Cecilia Henricson, Hugo Hesser, Maria Jannert, Robert Johansson, Felix Koch, Clara Möller, Doris Nilsson, Ali Sarkori, Kristin Silfvernagel, Ellinor Sellgren, Anett Sundqvist and Åsa Wrede for shared lunches and many good talks.

At my department, I have had the opportunity to collaborate with five colleagues in editing our own journal. Robert Aman, Camilla Forsberg, Anders Hallqvist, Erik Nylander and Fredrik Sandberg; it has been a great joy getting to know you and engaging with you in discussions and debates.

I am also grateful to the students who have trusted me with supervising their Master's and Bachelor's theses. Thank you Linnea Adenskog, Emma Birkehag, Linn Bergcrona, Therese Björck, Cecilia Franke, Yvonne Hofer, Amanda Hägg, Louise Johansson, Maja Krantz, Charlotte Lindberg, Katarina Marjanovic, Fanny Niklasson Wihlborg, Martina O'Hanlon, Camilla Olsson Halmetoja, Anna Pralica, Maria Wedeen, Madeleine Wickenberg and Mariana Östebo. It has been a great pleasure engaging in all of your projects.

Outside my own department, I am fortunate to have found engagement in my research at the Department of Child Studies. I am especially grateful for Associate Professor Karin Osvaldsson Cromdal's valuable comments on my $60 \%$ seminar. For my $90 \%$ seminar, I received comments from Professor Emerita Eva Magnusson at Umeå University. Thank you, Eva for your valuable comments.

I am lucky to have found Malena Gustavson at the Department of Gender Studies in Linköping, and Irina Schmitt at the Department of Gender Studies in Lund. Malena and Irina opened their hearts and minds to me in a way that meant a great deal to me. Thank you so much for your warmth, laughter, encouragement, pep talks and friendship. Thank you for role modelling your combination of good research and political activism. 
I also wish to express my gratitude to Katri Nieminen for involving me in her research project on fear of child birth. Thank you Katri, for engaging me in a truly important study, for sharing your insights with me, and for engaging in my life and family.

I am fortunate to have the best, wisest and most terrific friends on earth. My deepest thanks to:

Malin Axelsson, Emmy Dahl, Lina Engström, Anna Fagerström, Sharifeh Monireh Farsi, Malin Henriksson, Elin Kusmin, Lina Larsson, Silje Lundgren, Hanna Sjögren, Sarah Vinterlycka and Anna Wallsten, all members of my feministic pep group. Thank you for shared love, wisdom and many hours of pep talking. You are simply the best.

Magnus and Mikko Eneberg. We shared so many dreams and desires. As they ended up in failure, the only thing we had left was our friendship. And that is not the smallest thing. Thank you for the huge trust you put in me. I am so happy that the two of you became daddies at last!

Georgia Filippidou. Thank you for your amazing humour and sharp mind. Thank you for always welcoming me in your home and family. I am so glad that we re-found each other as friends.

Jenny Folkö Witt. Jenny, that you accepted my invitation for you to lead my daughter's funeral meant the world to me. You did a beautiful job, expressing the right things in the most emphatic way. Thank you so much.

Helena Kunstbergs, my lovely teenager. Helena is a true bundle of energy. Thank you for letting me enjoy for your warm laughter and fascinating imagination. I am impressed to see your huge capacity and skill as you care for your horse, Bella. I am confident that you have the ability to take on any challenge that you will meet in the future.

Lina Larsson. I have honestly never met a more insightful person than Lina. Lina, I love your capacity to identify patterns in the chaos 
of life, and to put words to your insights for me and others to share. Thank you truly for your love and encouragement.

Ina Nyberg Gruffman. Any time I find myself in emotional troubles, I turn to Ina. Ina, you are a true talent in validation and comfort. More than anything, thank you for standing by my side during the hardest day of my life, when I lost Myran. I could not possibly have found better support anywhere on earth.

Björn Paxling. Björn has an appetite for life that is seldom found among adults. Thank you, for sharing your expanding mind and thank you for love and shared joy.

Maria Padrón Hernández. Maria is my best informal academic supervisor. Maria, how I wish you and I could share reflections on life and politics on an everyday basis! Thank you so much for your engagement in my research and thank you for many years of friendship. Not the least, thank you for your brilliant support when I gave birth to Tove.

Kristin Winander. Getting to know Kristin has brought me along on a thrilling journey. Kristin is an insightful person who is highly engaged with forming a life that matches her values and needs. Kristin, thank you for showing me how a fluid mind can always find new paths.

And, hey, thank you Sandra Eriksson, Mats Dahlin, Lena Fröberg, Hannah Gruffman, Simon Holender, Natalia Iarochenko, Sofi Kärfve, Emy Lanemo, Tove Lundberg, Moa Nihlwing, Cornelia Orhagen Brusmark, Linda Paxling, Lina Strömfors and Katarina Tagesson for your love and wisdom.

My best home in the world is the small island Lilla Kornö. Thank you everyone on Lilla Kornö for friendship and company. A special thanks to the Berntsson, Gustavsson and Johansson families for taking care of the island, and to the Backlund, Brune, Fjellson, Hasselrot and Mohall families for good talks and many good childhood memories. 
Not only am I spoiled with the best of friends. I am also lucky to have a terrific family of origin. I owe each of you a thunderous thank you:

Birgitta Johansson, my aunt. Thank you for caring for me and my brother when we grew up, and for continuing to engage in my and my children's life.

Elisabeth Nilsson, my grandmother. Thank you for good childhood memories and for your engagement in your great grandchildren.

Gunnel and Henry Johansson, my grandparents. Gunnel, your humour and sharp comments are admirable. Thank you for engaging in my work with your support and interest. Henry, I appreciate your reflections as a professor emeritus. I am truly impressed that you continue to publish research articles past your $85^{\text {th }}$ birthday. Thank you for sharing your thoughts in your memoirs.

Martin Nilsson, my brother. Martin was my childhood playmate. We shared a room, a bunch of friends, games and fusses. Thank you, Martin, for your faithfulness. Whenever I have been going through troubles, you have always taken my part with admirable loyalty. I also appreciate and learn from your easy minded approach to life.

Erik Nilsson, my brother. I have often thought of Erik as my first child. In many respect, you actually are. You were the first baby whose diapers I changed, the first toddler I read a bedtime story for and put to sleep, the first child I brought on a vacation, and the first teenager I taught how to drive a boat and a car. Realizing that my baby brother is now an adult, just as wise, and more ambitious than anyone else, is an absolute thrill. Thank you Erik, for your constant support in anything, and thank you for remembering to give your sister a phone call now and then.

Maria Nilsson, my sister, has since birth been my darling. I left home when you were still small, but never felt that that disrupted our closeness. If Erik was my first child, then you were my second. For many years, to my great pleasure, Maria came to stay with me and my partner at weekends and holidays. Thank you Maria for your easy minded, positive and energy-filled life view. I love listening to your 
constant babbling, even though I sometimes wonder why me ears do not fall off.

Lena and Göran Nilsson, my parents. I grew up in a home where knowledge was central. Our dinner conversations concerned recent news and politics, and covered topics stretching from history and literature, to natural science and medicine. An encyclopaedia would always find its way to the table, to meet our desire for knowledge. I learned early on how to argue, question and listen. For my doctoral thesis, I owe great thanks to my parents, whose constant support, encouragement and trust have followed me during life. Dad, you had a terrific way of combining care and humour during my childhood. Mum, you have always been admirably patient. In all those years I cannot remember you ever raising your voice in a conflict. Not once. Being a parent myself, I have realized the extent of that accomplishment. Thank you both for your tireless support when life has been hard, for providing a home for me to return to and for your great engagement in your grandchildren.

Let me now turn to the warm, crazy, dynamic, loving and joyful family I have built for myself. I owe each of you my deepest love and gratefulness:

Emma Malmquist, my ex-wife and parent of my two older children. Thank you for joy and care during the years we spent together. Thank you also for your excellent way of caring for our children during the weeks they spend in your home. In particular, thanks to you and your wife Caroline for bringing Adrian into the world. Adrian Björklund is the most charming toddler and the best baby brother for my sons. Thank you, Adrian, for you sweetness and for being part of our lives.

Erik Tengstrand, my dear friend (always), partner (sometimes), and parent of my two younger children. Erik is the most stable, reliable and calm person that has ever been able to put up with me for any proper amount of time. Thank you for your compassion and your open heart and mind. In particular, thank you for shared closeness, comfort and support when we lost Myran, and thank you for being the best parent Tove could ever wish for. 
Emil Malmquist, my first born child. Emil is one of the wisest and most curious persons I have ever met. Already as a two year old, you challenged me with tricky questions and objections. When growing older, your mind has only grown sharper and your thoughts more reflexive. Thank you Emil, for all late night good talks, and for always challenging my opinions. Thank you for cuddles and a lot of shared laughter. I love you.

Nils Malmquist, my second child. Nils is a creative, easy minded and socially skilled person, who has shown lots of willpower and strong opinions as he has grown older. Nils, when you took your first breath my heart immediately expanded to twice the size it had been before. Thank you, sweetheart, for your jokes, ingenuity, and positive nature. It is amazing to accept your challenges for running competitions, and to realize that you actually run faster than me, despite me really trying to beat you. Thank you for your committed love and millions of hugs. I love you.

Myran Malmquist Tengstrand, my third child. Myran was the most beautiful baby in the world. I will always bear as a favourite memory our joint communication when you were buffing inside my belly. Thank you Myran, for each second of your way, way, way too short life and for the time I held you in my arms. I love you and I miss you every second.

Tove Malmquist Tengstrand, my fourth child. Tove has an energy and appetite for life that is amazing to share. Thank you for reminding me of the huge amazement in things that I had forgotten to be fascinated by, such as mirror reflections and the taste of a banana. Thank you, Tove, for all your big toothless smiles and your cute laughter. Thank you for wet kisses, and for still being small when your brothers grow up so fast. I love you.

Anna Malmquist, Lilla Kornö, April 2015 


\section{Articles}

The articles associated with this thesis have been removed for copyright reasons. For more details about these see:

http://urn.kb.se/resolve?urn=urn:nbn:se:liu:diva-117933 

165. RUTERANA, PIERRE CANISIUS. The Making of a Reading Society. Developing a Culture of Reading in Rwanda. 2012. ISBN: 978-91-7519840-8

166. SANDBERG, FREDRIK. Recognition of Prior Learning in Health Care. From a Caring Ideology and Power, to Communicative Action and Recognition. 2012. ISBN: 978-91-7519-814-9

167. FÄGERSTAM, EMILIA. Space and Place. Perspectives on Outdoor Teaching and Learning. 2012. ISBN: 978-91-7519-813-2

168. FALKENSTRÖM, FREDRIK. The Capacity for Self-Observation in Psychotherapy. 2012. ISBN: 978-91-7519-797-5

169. BENNICH, MARIA. Kompetens och kompetensutveckling i omsorgsarbete. Synen på kompetens och lärande i äldreomsorgen - i spänningsfältet mellan samhälleliga förutsättningar och organisatoriska villkor. 2012. ISBN: 97891-7519-777-7

170. RUSANGANWA, JOSEPH. Enhancing Physics Learning through Instruction, Technical Vocabulary and ICT. A Case of Higher Education in Rwanda. 2012. ISBN: 978-91-7519-739-5

171. MBABAZI, PENELOPE. Quality in Learning in Rwandan Higher Education: Different Stakeholders' Perceptions of Students' Learning and Employability. 2013. ISBN: 978-91-7519-682-4

172. BYSTRÖM, ERICA. Ett lärorikt arbete? Möjligheter och hinder för undersköterskor att lära och utvecklas i sjukvårdsarbetet. 2013. ISBN: 978-917519-679-4

173. KAGWESAGE, ANNE MARIE. Coping with Learning through a Foreign Language in Higher Education in Rwanda. 2013. ISBN: 978-91-7519-640-4

174. MUTWARASIBO, FAUSTIN. Understanding Group-based Learning in an Academic Context: Rwandan Students' Reflections on Collaborative Writing and Peer Assessment. 2013. ISBN: 978-91-7519-633-6

175. MÅRDH, SELINA. Cognitive erosion and its implications in Alzheimer's disease. 2013. ISBN: 978-91-7519-612-1

176. HARLIN, EVA-MARIE. Lärares reflektion och professionella utveckling Med video som verktyg. 2013. ISBN: 978-91-7519-611-4

177. ÖSTERGREN, RICKARD. Mathematical Learning Disability. Cognitive Conditions, Development and Predictions. 2013. ISBN: 978-91-7519-565-0 
178. ENGVALL, MARGARETA. Handlingar i matematikklassrumet. En studie av undervisningsverksamheter på lågstadiet då räknemetoder för addition och subtraktion är i fokus. 2013. ISBN: 978-91-7519-493-6

179. JOHANSSON, ROBERT. Treating depression and its comorbidity. From individualized Internet-delivered cognitive behavior therapy to affectfocused psychodynamic psychotherapy. 2013. ISBN: 978-91-7519-467-7

180. BERGMAN NORDGREN, LISE. Individually tailored internet-based cognitive behavioural therapy for anxiety disorders. 2013. ISBN: 978-91$7519-459-2$

181. FREJD, PETER. Modes of Mathematical Modelling. An Analysis of how modelling is used and interpreted in and out of school settings. 2014. ISBN: 978-91-7519-414-1

182. AMAN, ROBERT. Impossible Interculturality? Education and the Colonial Difference in a Multicultural World. 2014. ISBN: 978-91-7519-348-9

183. NYLANDER, ERIK. Skolning i jazz. Värde, selektion och studiekarriär vid folkhögskolornas musiklinjer. 2014. ISBN: 978-91-7519-347-2

184. GRADIN FRANZÈN, ANNA. Disciplining freedom: Treatment dilemmas and subjectivity at a detention home for young men. 2014. ISBN: 978-917519-344-1

185. ENGSTRÖM, ANNIKA. Lärande samspel för effektivitet. En studie av arbetsgrupper i ett mindre industriföretag. 2014. ISBN:978-91-7519-345-8

186. ELWÉR, ÅSA. Early Predictors of Reading Comprehension Difficulties. 2014. ISBN: 978-91-7519-281-9

187. LARSON, NICLAS. Matematikämnet och stadiebytet mellan grundskolan och gymnasieskolan. En enkät- och klassrumsstudie. 2014. ISBN: 978-917519-196-6

188. LY, HOA. Use of a Smartphone Application in the Treatment of Depression - The New Wave of Digital Tools for Psychological Treatment. 2015. ISBN: 978-91-7519-136-2

189. HANSSON, PER-OLOF. New ways of learning. Participatory action research and Kenyan runners' appropriation of smartphones to improve their daily lives and participation in m-learning. 2015. ISBN: 978-91-7519-124-9

190. BOLLDÈN, KARIN. Online teaching practices. Sociomaterial matters in higher education settings. 2015. ISBN: 978-91-7519-123-2 